\title{
Marine storms in coastal tourist areas of the Canary Islands
}

\author{
Amalia Yanes Luque ${ }^{1}$ José A. Rodríguez-Báez ${ }^{2} \cdot$ Pablo Máyer Suárez ${ }^{3}$. \\ Pedro Dorta Antequera ${ }^{2}$ - Abel López-Díez ${ }^{2}$ (D) Jaime Díaz-Pacheco ${ }^{2}$. \\ Emma Pérez-Chacón ${ }^{3}$
}

Received: 24 January 2021 / Accepted: 16 June 2021

(c) The Author(s) 2021, corrected publication 2021

\begin{abstract}
The small island areas oriented to coastal tourism are highly vulnerable to marine storms, given the fluctuation of this economic sector and the increase in its exposure due to the increasing anthropogenic presence on the coastline. In this context, the storms between 1958 and 2017 are studied here in the most important tourist enclaves of Tenerife and Gran Canaria, located in the municipalities of Arona and Adeje (SW of Tenerife) and in San Bartolomé de Tirajana and Mogán (S-SW of Gran Canaria). In order to perform the analysis, wave data from State Ports (Spain) (SIMAR-44 nodes, Ministry of Transport, Mobility and Urban Agenda of Spain) are used. A statistical study of the phenomena can help establish a threshold for the identification of a marine storm based on a significant wave height $\left(H_{\mathrm{s}}\right)$ of $2.7 \mathrm{~m}$ in Arona and Adeje and $1.7 \mathrm{~m}$ in San Bartolomé de Tirajana and Mogán. The application of this threshold identified 144 episodes in the SW of Tenerife and 154 in the $\mathrm{S}-\mathrm{SW}$ of Gran Canaria. Their behavior is examined from, on the one hand, the duration, seasonality, type of waves and degree of severity that characterizes them; and, on the other, from the state of the atmosphere that concurs in its genesis by means of the Wetterzentrale synoptic maps. Finally, a first assessment of the effects of these stormy phenomena is made using local press reports on drowning, damage to urban furniture and port infrastructures and loss of sand on the beaches.
\end{abstract}

Keywords Marine storm $\cdot$ Swell/sea $\cdot$ Danger $\cdot$ Storm Power Index (SPI) $\cdot$ Tourism

Amalia Yanes Luque

ayanes@ull.edu.es

1 Department of Geography and History, University of La Laguna (ULL),

San Cristóbal de La Laguna, Tenerife, Spain

2 Territorial Management and Risks Group (GEORIESGOS), Disaster Risk Reduction and Resilient Cities Group, University of La Laguna (ULL), San Cristóbal de La Laguna, Tenerife, Spain

3 Physical Geography and Environment Group, Institute of Oceanography and Global Change (IOCAG), University of Las Palmas de Gran Canaria (ULPGC), 35214 Telde, Gran Canaria, Spain 


\section{Introduction}

The increasing and continued social use of the coast may convert the sea into a risk factor. This is due to the danger that storms can sometimes pose, particularly in coastal areas of tourist specialization in island territories. The alteration of daily life and the economic and human losses caused by this type of phenomenon demand a better knowledge about the exposure of these coastal sectors and an obligatory reflection on the adoption of measures that reduce the impacts of these high energy events (Costas et al. 2015).

Social concern about marine storms is, on the one hand, a response to the threat they pose to tourist infrastructures located on the coast; and, on the other, a reaction to the fact they are phenomena that occur in a context of climate change, with the transformations that this could bring about in sea level and in the intensity and frequency of adverse meteorological manifestations (IPCC 2013, 2014). Furthermore, it is an accepted fact that this change will accentuate the vulnerability of small islands, even though the scientific literature regarding the impacts on them is limited, due to the difficulty of making statistical projections with the scales of current global models (IPCC 2014).

Despite such difficulties, the assessment of disasters due to storms at sea requires an examination of their behavior, evolution and consequences. This is necessary in order to assess their danger and the population's ability to adapt and mitigate their effects, especially when it comes to small, highly exposed spaces with a tourist economy (UNISDR 2009; Tsai and Chen 2011). In this respect, the relevance of a risk analysis based on its estimation, identification and understanding is undoubted (Van Western 2013). This is demonstrated by the importance of these aspects in international consensus documents related to their reduction, such as the Sendai framework 2015-2030 (UN 2015a) and the Paris Agreement (UN 2015b, article 8). Therefore, the most frequently applied methods in the risk study at a local scale are centered on determining the danger and its relationship with exposure and vulnerability, in order to estimate its possible harmful effects (Carreño et al. 2002).

Starting from the last above point, the characterization of the storms is performed in this investigation with wave data obtained from buoys and numerical models. The statistical research of waves makes it possible to determine the usual wave regime and identify its behavior in extreme situations (Mendoza and Jiménez 2008; Rangel-Buitrago and Anfuso 2010, 2013, 2014; Menéndez et al. 2014; Anfuso et al. 2015; Yanes et al. 2007; Yanes and Marzol 2009; Rodríguez-Báez et al. 2017; Molina et al. 2019). The spatial incidence of the impacts of these extreme situations on a local scale is usually based on the information provided about them by different media (press, radio, television ...) and on the losses reported in previous studies (Máyer 2011).

This work aims to provide a better knowledge of the risk of marine storms originating in the North Atlantic, by analyzing the events that occurred between 1958, the first year of the historical series of wave data from State Ports (Spain) and 2017 in both main coastal tourist enclaves of the Canary Islands: Los Cristianos, Las Américas-Fañabé and Caleta de Adeje, in the municipalities of Arona and Adeje (SW of Tenerife), and Maspalomas, Anfi del Mar-Patalavaca and Puerto Rico-Amadores, in San Bartolomé de Tirajana and Mogán (S-SW of Gran Canaria). The work focuses on defining and interpreting the dangerousness of the identified episodes, based on their duration, spatial distribution, seasonality, type of waves, degree of severity and types of weather that occur in their genesis. The data used for this are from State Ports (SIMAR-44 Nodes) (Fig. 1) and Wetterzentrale. In addition to this, there is the assessment of the damages and losses caused as reported in the press. 


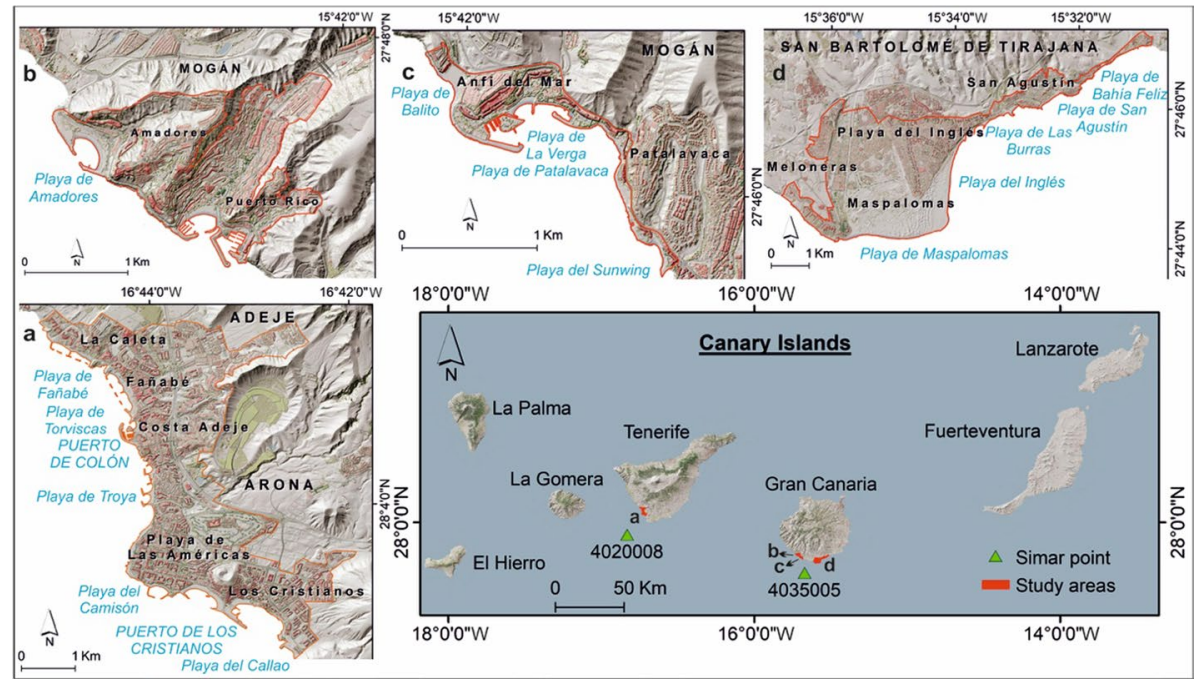

Fig. 1 Location of the study area and SIMAR-44 nodes. Upper image: tourist centers of Anfi del Mar-Patalavaca (b), Puerto Rico-Amadores (c) and Maspalomas (d) (S-SW of Gran Canaria). Bottom left image: Los Cristianos, Las Américas-Fañabé and Caleta de Adeje tourist centers (a) (SW of Tenerife); lower right image: Canary Islands archipelago and Simar nodes. Source: Cartographic base obtained from Cartográfica de Canarias, S.A

\section{Study area}

The study area covers a $19 \mathrm{~km}$ continuous seafront between Los Cristianos, Las América-Fañabé and Caleta de Adeje, in the SW of Tenerife, and $30.5 \mathrm{~km}$, although with discontinuous spatial development, and between Maspalomas, Anfí del Mar-Patalavaca and Puerto Rico-Amadores, in the S-SW of Gran Canaria (Fig. 1).

The current configuration of these spaces can be defined by the term artificiality, since regenerated beaches, promenades, breakwaters and terraces and tourist accommodation occupy $69 \%$ of the coastal strip. Only $31 \%$ of it retains its natural character (Table 1). Such a configuration is the product of the accommodation of the coast to the demands of sun and beach tourism. Starting in the 1960 s, it replaced agriculture for export as the basis of the Canary economy (Pérez-Chacón et al. 2007). Proof of this is that tourism activity accounts for more than $40 \%$ of employment in the Canary archipelago and that its contribution to the regional gross domestic product exceeds $35 \%$ (Exceltur 2019).

The impact caused by the new land use is, however, uneven in the study area. According to Ferrer-Valero et al. (2017), it is severe in Los Cristianos (Arona) and Las Américas-Fañabé (Adeje), where $72 \%$ of the coastline (Table 1) is the home of the tourist-residential nucleus and the commercial, sports, recreational and regular passenger traffic complexes, which have transformed the primitive hamlet with a fishing pier and where shipments of local agricultural products were once loaded. The result is a space with 11,893 tourist beds and 60\% occupancy in 2019 in Los Cristianos and 69,721 beds and 74\% occupancy in Las Américas-Fañabé (Instituto Canario de Estadística, hereinafter ISTAC 2020). In these enclaves, tourism revolves around sandy beaches of Saharan 


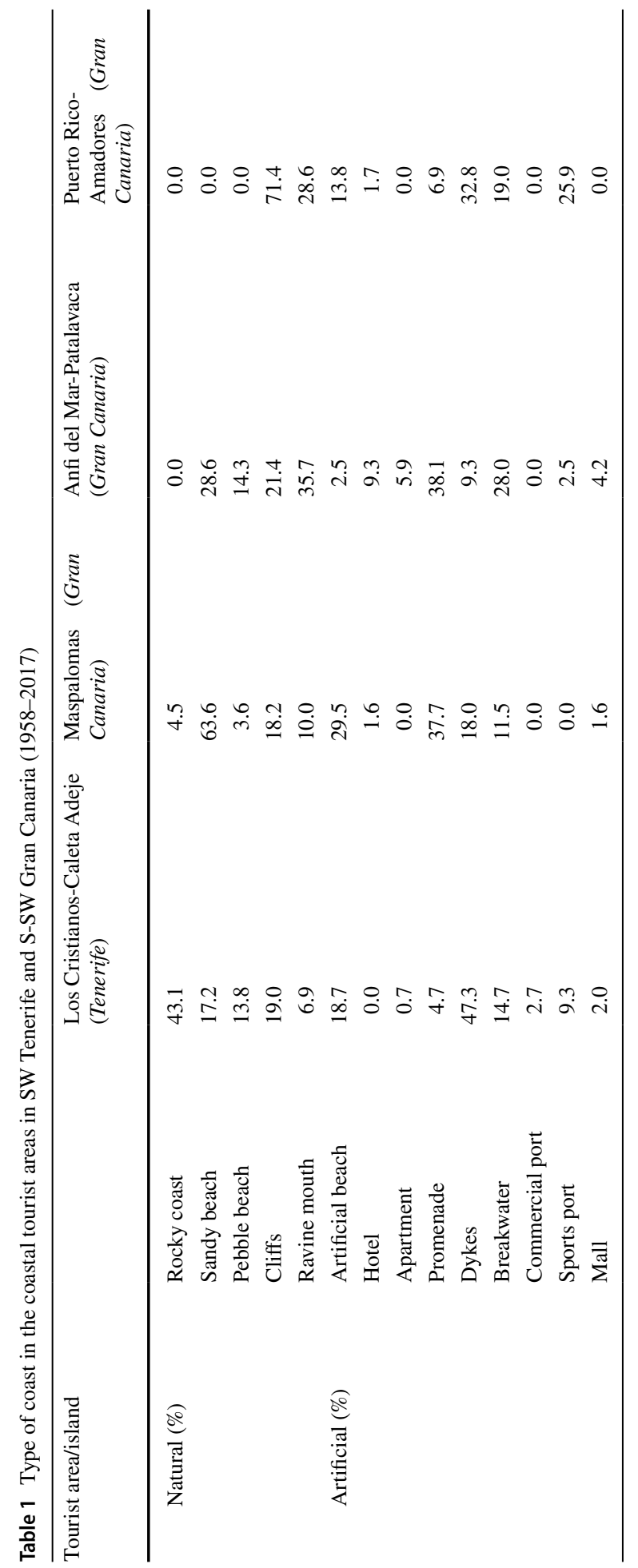


origin and crushed pebbles (18.7\%). These cover the original substrate of pebbles and require the construction of breakwaters and dykes (58.4\%) for their retention. They occupy a large proportion of the marine area in relation to the length of the newly created beaches (Escartín 2016) (Fig. 2). The degree of intervention is even higher in Anfi del Mar-Patalavaca and Puerto Rico-Amadores (Mogán), with almost 90\% of artificial coastline made up mostly of dykes and breakwaters (48\%), promenades (20\%) and artificial beaches (15\%) (Table 1). Although originally small beaches were found along the coastline at the mouths of the ravines between cliffs, the growth of tourism in recent decades covers the bottom and slopes of the ravines with urban development that host 27,009 accommodation places and 67\% occupancy in 2019 (ISTAC 2020). Such development involves large clearings, which modify the previous topography and have a great environmental impact (Macías-González 2017).

Maspalomas is the only coastal stretch with a predominance of natural elements, linked to sandy beaches (63.6\%) and to a lesser extent to cliffs (18.2\%) and ravine mouths (10\%) (Table 1). This is due to the high degree of protection afforded to this $4 \mathrm{~km}^{2}$ complex because of the natural values of its two wide beaches $(6 \mathrm{~km})$, mobile dunes and coastal lagoon (Fig. 2). All in all, tourism introduces notable alterations, bearing in mind that the beach-dune system is surrounded by an urban area of $13.7 \mathrm{~km}^{2}$, where 85,316 tourist places are concentrated (ISTAC 2019; Hernández-Calvento 2006; García-Romero et al. 2016; Hernández-Cordero et al. 2017).

\section{Sources and methodology}

For the purposes of this work, a marine storm is understood to be any episode in which the height, behavior and energy content of waves clearly differ from the usual wave regime, during a given period of time. Other aspects of a marine storm are the need for a rapid response on the coast and the possibility of it becoming a threat to the coastal system and the population living there (Mendoza and Jiménez 2008; Benavente et al. 2009; Mosso et al. 2009; Rangel-Buitrago and Anfuso 2014; Garmendia et al. 2017; Molina et al. 2019).
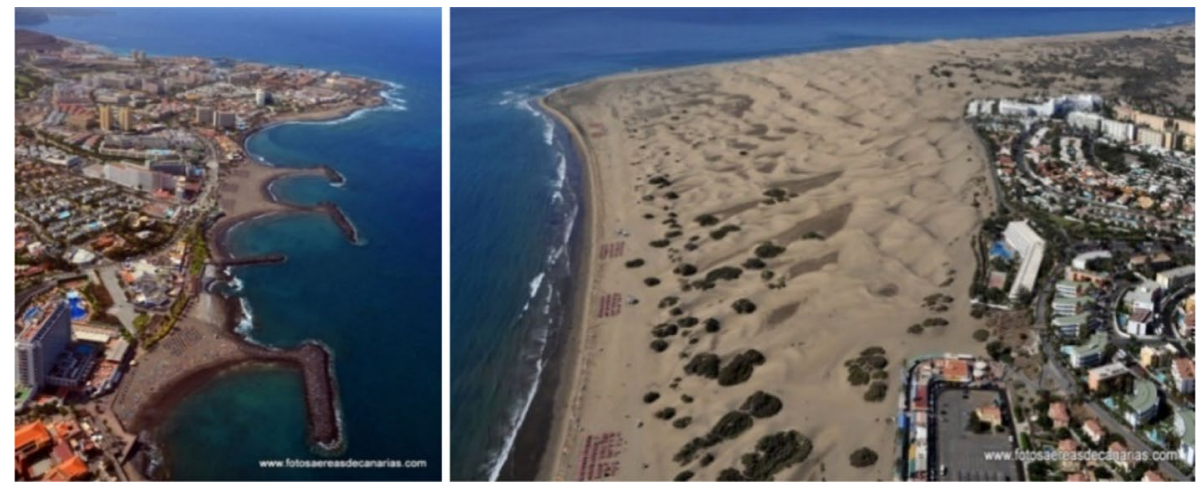

Fig. 2 Contrast between the artificial character of the Las Américas-Fañabé coastline (SW of Tenerife) (left image) and the naturalness of the Maspalomas dune field (S-SW of Gran Canaria) (right image). Source: www.fotosaereasdecanarias.com 


\subsection{Sources}

The materials used for the analysis of marine storms are varied and come from the following different sources:

a. wind and directional wave data from the mathematical models of wave generation and propagation from the Simar-44 set (State Port Oceanographic Data Bank). From these, $4,020,008$ was chosen for the SW of Tenerife $\left(27.92^{\circ} \mathrm{LN}\right.$ and $\left.16.83^{\circ} \mathrm{LW}\right)$ and 4,035,005 for the S-SW of Gran Canaria $\left(27.67^{\circ} \mathrm{LN}\right.$ and $\left.15.58^{\circ} \mathrm{LW}\right)$ (Fig. 1). These provide 24 daily recordings of significant wave height $\left(H_{\mathrm{s}}\right.$, meters $)$, peak-period ( $T_{\mathrm{p}}$, seconds), wave direction (degrees), as well as wind direction and speed (degrees; meters/second). The height of the maximum wave $\left(H_{\max }\right.$, meters) and the wavelength $(L$, meters) are calculated from the first two parameters. The analysis of all of the above means that it is possible to define the habitual regime of the waves and to delimit extreme situations.

b. data on atmospheric conditions from Wetterzentrale weather maps to determine the synoptic situation at the origin and evolution of storms.

c. reviews in the press, as this is a medium that quickly reports on disasters of natural origin (Torres et al. 1994; Máyer 1999; Yanes and Marzol 2009; Yanes 2017). The data on the triggering of the marine storm, affected localities and the type and degree of severity of its damage come from Diario de Avisos, El Día, Diario de Las Palmas, La Provincia and Canarias 7. These are regional newspapers with a large circulation and wide coverage in terms of time, which in the case of some go back to the first decades of the last century. The records on the incidence of storms begin in the $1970 \mathrm{~s}$, a result of the lack of information beforehand given that the study area was largely uninhabited. Also included in this section are references to damage from a previous work (Máyer 2011).

\subsection{Methodology}

The treatment of the data obtained is based on a statistical analysis of the maritime climate and its extreme events, as well as an examination of the prevailing atmospheric conditions and the content of the press reports about the storms between 1958 and 2017.

The study of the waves and wind involves the characterization of the annual and seasonal average regime from the average values of $H_{\mathrm{s}}, H_{\max }, T_{\mathrm{p}}, L$, wave direction and wind direction and speed at 9:00 and 18:00:00 h, because they are the times that best capture the changes that the breezes may cause (Pardo 1991: 36). These parameters are examined on a daily and hourly basis to determine the behavior and fluctuations of the waves in sea storms.

The identification of extreme events requires the setting of an identifying threshold (Yanes et al. 2007; Mendoza and Jiménez 2008; Yanes and Marzol 2009; Almeida et al. 2011; Del Río et al. 2012; Rangel-Buitrago and Anfuso 2014; Anfuso et al. 2015; Rodríguez-Báez et al. 2017), which is established from the mean daily height of the $H_{\mathrm{s}}$. Although there seems to be "no absolute threshold from which a wave movement in the sea is considered an extreme event" (Afonso 2011: 69), the $\mathrm{P}_{99}$ is tested in this work to collect the exceptional recordings. The $\mathrm{P}_{90}$ and $\mathrm{P}_{95}$ are discarded despite their frequent use in many investigations (Mosso et al. 2009; Menéndez et al. 2012; Rangel-Buitrago and Anfuso 2014; Anfuso et al. 2015; Eichentopf et al. 2019), because the $H_{\mathrm{s}}$ value 
resulting from its calculation is close to that of the annual average in the tourist enclaves of both islands (Table 2).

In the same way, the value resulting from the calculation of the $H_{\mathrm{s}}$ is less than the minimum height of the $H_{\mathrm{s}}$ that the Maritime Works Recommendations (ROM03-91) take into account as a cut-off threshold for the consideration of storm situations and reliability of coastal infrastructures in the Canary Islands (Ministry of Public Works and Transport 1992: 34), at least in Tenerife. This is not the case in Gran Canaria, where the percentile in question does not exceed this height. The choice of another superior percentile $-\mathrm{P}_{99.5}, \mathrm{P}_{99.8} \ldots$ (Almeida et al. 2011) — is considered inoperative, because extreme episodes are reduced too much; situations with a social impact on the coast, as reported in the press, are even eliminated. Therefore, starting at $\mathrm{P}_{99}$, the cutoff threshold is set at $2.7 \mathrm{~m}$ of $H_{\mathrm{s}}$ in the SW of Tenerife and $1.7 \mathrm{~m}$ in the S-SW of Gran Canaria.

After consulting the criteria used to specify the course, continuity and separation between storms (Ferreira 2006; Mendoza and Jiménez 2008; Rangel-Buitrago and Anfuso 2010, 2014; Almeida et al. 2011; Del Río et al. 2012; Anfuso et al. 2015), an event is considered a marine storm here if the established cut-off wave height threshold is equaled or exceeded for twelve consecutive hours. In this way, its development coincides with a complete tidal cycle on a semi-diurnal coast (Rangel-Buitrago and Anfuso 2014; Anfuso et al. 2015), such as the Canary Islands; this period is sufficient, in addition, to generate processes of interest on the coast (Mendoza and Jiménez 2008). The separation between storms is made using the Peak Over Threshold (State Ports, Spain.), which is a method of extreme values by which storms are understood to be independent if five days elapse between them. In the selected tourist centers, this time is reduced, in some cases, when there are at least twelve hours between two episodes in which the $H_{\mathrm{s}}$ not only does not exceed the threshold, but is almost equal to or less than its average height in the season of the year in which the storm occurs. To this is added the classification of storms by their energy content, according to the Storm Power Index (SPI $=H_{\mathrm{s}} 2 \mathrm{td}$ ) proposed by Dolan and Davis (1992). This concerns the hours of duration of the storm and the $H_{\mathrm{s}}$, with the highest value recorded throughout its development normally being used (Rangel-Buitrago and Anfuso 2014; Anfuso et al. 2015). The result is the classification of marine storms into weak (Class I), moderate (Class II), significant (Class III), severe (Class IV) and extreme (Class V), using the Jenks and Caspall natural breaks function (1971, in Anfuso et al. 2015).

The ascription of storms at sea to the type of weather that triggers them is another aspect considered here. In order to do this, the atmospheric configuration recorded two or three days before is explored. Special attention is paid to the location and value reached by the pressure center or centers, as well as the trajectory they follow with respect to the Canary Islands.

Table $2 H_{\mathrm{s}}$ values (m) used to set the identifying threshold for a marine storm in coastal tourist areas in SW Tenerife and S-SW Gran Canaria (1958-2017). Source: State Ports (Spain)

\begin{tabular}{|c|c|c|c|c|c|}
\hline Tourist area/island & Annual mean & R.O.M. 03-91 & $\mathrm{P}_{90}$ & $\mathrm{P}_{95}$ & $\mathrm{P}_{99}$ \\
\hline $\begin{array}{l}\text { Los Cristianos, Las Américas-Fañabé and Caleta de Adeje } \\
\text { (Tenerife) }\end{array}$ & 1.0 & 1.5 & 1.7 & 2.0 & 2.7 \\
\hline $\begin{array}{l}\text { Maspalomas, Anfi del Mar-Patalavaca and Puerto Rico- } \\
\text { Amadores (Gran Canaria) }\end{array}$ & 0.6 & 2.0 & 1.1 & 1.2 & 1.7 \\
\hline
\end{tabular}


Finally, the consequences of extreme marine events are examined by connecting the intensity of the storms, the SPI values and the content of the press reviews. In the latter case, attention is paid to the volume and formal and argumentative treatment of the news, its appearance on the front page and/or inside pages and the inclusion or not of photographs. As a result, the episodes causing much damage to buildings and basic infrastructure on both islands are classified as very severe; on the other hand, those that cause erosive damage in some of the tourist centers of the work area are considered less serious.

The consequences are also studied taking into account the nature of the coast and the damage. To this end, a distinction is made between a natural coast, made up of a rocky coastline, cliffs, sandy beaches, pebble beaches and ravine mouths, and an artificial coast, made up of tourist accommodation in hotels and apartments, promenades, dykes, breakwaters, commercial ports, marinas and shopping centers. Artificial beaches built on a natural pebble surface are also included in this group, because their dynamics have already changed. Different subtypes are established in both categories, depending on what predominates in more than $50 \%$ of cases. For the damage examination, the coastline is segmented into sections of $100 \mathrm{~m}$ in length and an inland limit of $100 \mathrm{~m}$, depending on the threshold established by the Spanish coastal law for protected area limits (Law 2/2013). In each section, the damage that is recorded is inventoried. The result is the identification of damage linked to sea floods, breakages due to wave action, loss of property and people and deterioration in the natural environment.

\section{Results}

The storm analysis is on a coastal area with a maritime climate defined by low energy waves. This is typical of this coast, with a frequency of coastlines with waves of generally less than $1 \mathrm{~m}$, in the absence of storm episodes and a high degree of protection with respect to other exposed coasts (Jackson et al. 2002). In the study area as a whole, the annual mean height of the $H_{\mathrm{s}}$ is $0.8 \mathrm{~m}$, with the $H_{\text {max }}$ being $1.4 \mathrm{~m}$. In addition to this, in Los Cristianos, Las Américas-Fañabé and Caleta de Adeje, waves of $0-1 \mathrm{~m}$ are recorded in $55 \%$ of the days of the year, and this value is $87 \%$ in Maspalomas, Patalavaca-Anfi del Mar and Puerto Rico-Amadores.

The recording of waves of $0.5-1 \mathrm{~m}$ and $6-10 \mathrm{~s}$ (52\% in the SW of Tenerife and $54 \%$ in the S-SW of Gran Canaria) also confirms the moderate nature of an average annual regime in which the sea prevails. There are, however, certain distinctive nuances, as the waves reach higher values in the tourist enclaves of the SW of Tenerife. This is the case of an $H_{\mathrm{s}}$ registering $1-2 \mathrm{~m}$ of annual mean height (58.3\%), an $H_{\max } 2-4 \mathrm{~m}(35.2 \%)$, while an $L$ is $100-200 \mathrm{~m}(41.3 \%)$ and a $T_{\mathrm{p}}$ of $10-14 \mathrm{~s}(38.7 \%)$. This is due to the higher incidence of non-local waves, on an island that is located further to the north and to the west than Gran Canaria in the context of the archipelago and, therefore, more exposed to Atlantic storms.

\subsection{General characteristics of marine storms}

Applying the cut-off threshold set, there have been 144 maritime storms in the SW of Tenerife and 154 in the S-SW of Gran Canaria. These present specific attributes according to the following aspects: 
a. Duration the storms analyzed present a variable development, depending on the number of days in which they occur and whether or not they continue over time. Almost three quarters of the total are single events, when the $H_{\mathrm{s}}$ always exceeds the cut-off threshold and there is no interruption in its evolution. Of more or less reduced extension, it is worth mentioning those that last between 0.5 and 1 and 1-2 days, while those of 4 or more are scarce (Table 3).

The others are discontinuous episodes, since the $H_{\mathrm{s}}$ is lower than the threshold in some cases. They are usually of a non-negligible amplitude, because, apart from the differences between the island tourist centers, there are many that last 3-4 days or more. A single interruption of 1-2.5 days is recorded. During the same storm, the height of the $H_{\mathrm{s}}$ is $0.3-0.8 \mathrm{~m}$ lower than the cut-off threshold in Gran Canaria (17-19/1/1963, 02-03/1/1981 and 18-20/12/2007) and 0.7-1.4 $\mathrm{m}$ in Tenerife (20-25/12/1973, 22-27/10/1999 and 17-19/1/2014). The storms with 2, 3 and even 4 breaks in the storm are not unknown, especially in Gran Canaria (26-28/I/1983, 16-18/3/1993 and 14-19/ II/2013). In general, these breaks last between 0.3 and 1 day, with the drop in $H_{\mathrm{s}}$ being $0.2-0.4 \mathrm{~m}$ and the time between them 0.5 and 1.5 days.

b. Distribution the degree of affectation is another feature to be noted, taking into account the changes registered between the localities of the study area, depending on whether the storms are independent, simultaneous or partially simultaneous. The former occur exclusively in the tourist enclaves of one of the islands, as is found in up to $70 \%$ of cases. Of the latter, only $3.4 \%$ occur at the same time in the SW of Tenerife and S-SW of Gran Canaria, which are single events lasting 1.5-3.5 days (14-15/2/1981, 04-07/12/1991 and 19-21/2/2004). The remaining $26.6 \%$ correspond to extreme events that mostly take place between 1 and $2(41.5 \%)$ and 2-4 days (28.1\%). In this case, the beginning and a good part of the development of the event or this and its end coincide in all tourist centers (05-06/2/1972, 13-14/1/1997 and 04-05/3/2014).

c. Annual and seasonal distribution versatility largely defines the recording of marine storms, in relation to their frequency throughout the statistical series studied (Fig. 3).

This shows, on the one hand, that there are on average 2 annual storms originating in the SW of Tenerife and 3 in the S-SW of Gran Canaria; and, on the other, that there is a noteworthy interannual irregularity, given that in some years there are 4 storms (SW Tenerife: 1963, 1972, 1974, 1979, 1987, 1991 and 2001; S-SW Gran Canaria: 1979, 1987 and 1999), while in others there are 5 (SW Tenerife: 1982 and 1986), 6 (SW Tenerife: 1989, 1996 and 2014; S-SW Gran Canaria: 1996 and 2015) and even 9 (S-SW Gran Canaria: 2012) and 10 (S-SW Gran Canaria: 2013 and 2014). However, there seems to be an increasing tendency in the number of stormy episodes, with an annual registered growth rate of $19.2 \%$ in the SW of Tenerife and $30.6 \%$ in the S-SW of Gran Canaria. This fact is particularly relevant in Gran Canaria, especially in the last decade.

From a seasonal perspective, storms are concentrated in winter, a time when $66.8 \%$ of the average annual recordings are made. These are followed by storms in the spring (18.8\%) and autumn (12.4\%), whose weight has tended to increase in recent years; those in the summer have, for their part, a limited significance (2\%). When denoted by tourist enclaves, however, there are less autumn storms in the S-SW of Gran Canaria $(9.1 \%)$ than in the SW of Tenerife (16\%) and the inexistence of storms in the summer in Tenerife. 


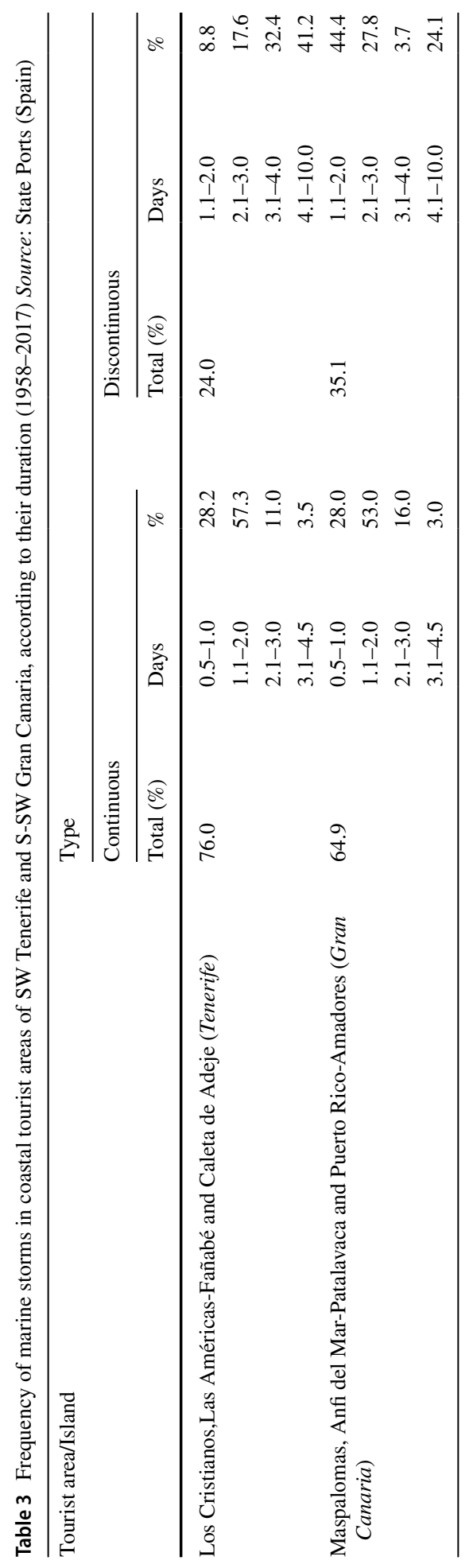




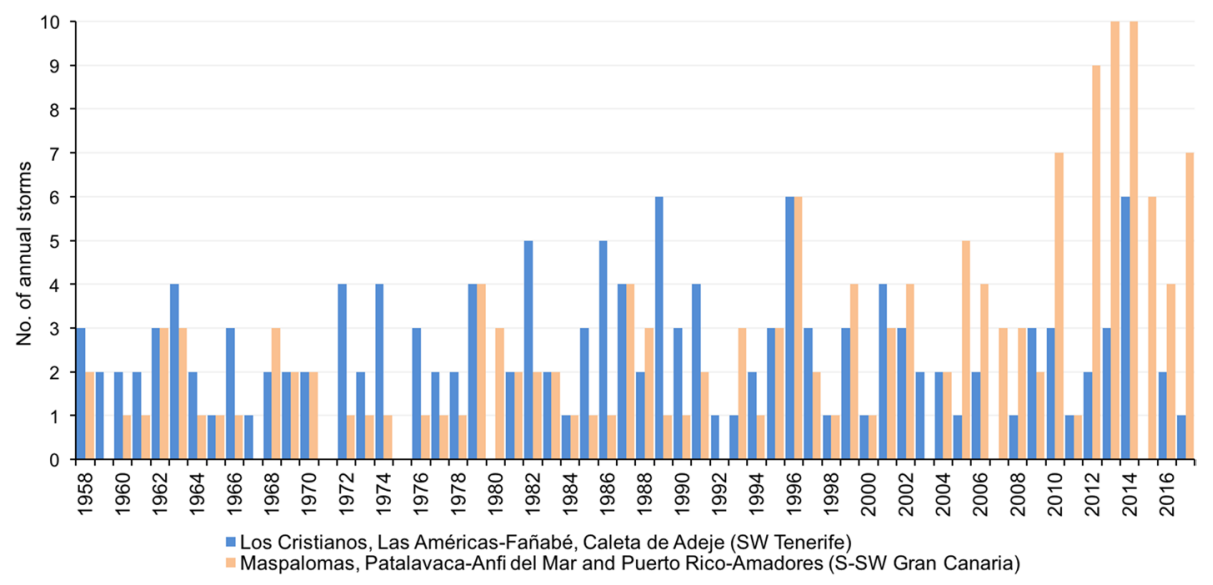

Fig. 3 Periodicity of the marine storms that occurred in coastal tourist areas of SW Tenerife and S-SW Gran Canaria (1958-2017). Source: State Ports (Spain)

d. Type of wave the analysis of the storms makes it possible to differentiate between swell and sea events. Although both are present in the scope of the study, the swell intervenes in $88.2 \%$ of the storms identified in Los Cristianos, Las Américas-Fañabé and Caleta de Adeje and the sea in $85.7 \%$ of those in Maspalomas, Patalavaca-Anfi del Mar and Puerto-Rico Amadores. Both have specific traits, depending on the behavior and value of their parameters.

Marine swell storms are, fundamentally, regular single episodes (78\%), with a height of $H_{\mathrm{s}}$ that rises progressively from the hours before the center of the storm, where it tends to remain for a certain time and then gradually decreases until it finishes (Fig. 4). For 1.0-2.5 days, waves from the NW-NNW and W arrive from the Northeast Atlantic with a fetch of about $3000 \mathrm{~km}$, long $T_{\mathrm{p}}(13.9 \mathrm{~s})$, and appreciable $L(300-400 \mathrm{~m}), H_{\mathrm{s}}$ of $3.1 \mathrm{~m}$ and $H_{\max }$ of $5.2 \mathrm{~m}$, although they sometimes exceed 5 and $9 \mathrm{~m}$. This occurs in a context with prevailing winds from the fourth quadrant of $22.1 \mathrm{~km} / \mathrm{h}$ average speed. This is high in the wave generation area but not in the Canary Islands region. In this case, at certain times, however, speeds of 40 and even $60 \mathrm{~km} / \mathrm{h}$ are exceeded (SW Tenerife: 02-03/12/1958, 18-19/12/1972, 20-23/12/1996 and 27/2-3/3/2006). This pattern differs in some of the other swell storms (22\%) (Fig. 4). This is the case of those which have an $H_{\mathrm{s}}$ lower than the cut-off threshold at one or more moments of the 3-6 days of their development. These are discontinuous events with uneven waves (SW Tenerife: 03-08/11/1962, 07-11/1/ 1994, 15-17/2/2011 and 06-09/1/2014).

Perhaps the most remarkable aspect of sea storms is the relative abruptness of their onset. This is defined by the oscillations and/or rapid fall of the $T_{\mathrm{p}}$ and an $H_{\mathrm{s}}$ that doubles its height in a period of 6-12 h with respect to the previously existing one (Fig. 5). After this phase, the fluctuations of these parameters are minimal in their subsequent rise and fall. This happens in single episodes $(62.1 \%)$ that generally elapse over a period of between 0.5 and 1.5 days. During this time, the coastline is hit by waves from the WSWSW and NE-ENE, related to flows from the third and first quadrant of $34.8 \mathrm{~km} / \mathrm{h}$ of average speed and a maximum speed of $50-60 \mathrm{~km} / \mathrm{h}$. They also have a short $T_{\mathrm{p}}(7.6 \mathrm{~s})$, reduced $L$ $(<100 \mathrm{~m}), H_{\mathrm{s}}$ of $2 \mathrm{~m}$ and $H_{\max }$ of $3.5 \mathrm{~m}$, which sometimes reaches 4 and almost $7 \mathrm{~m}$ in 

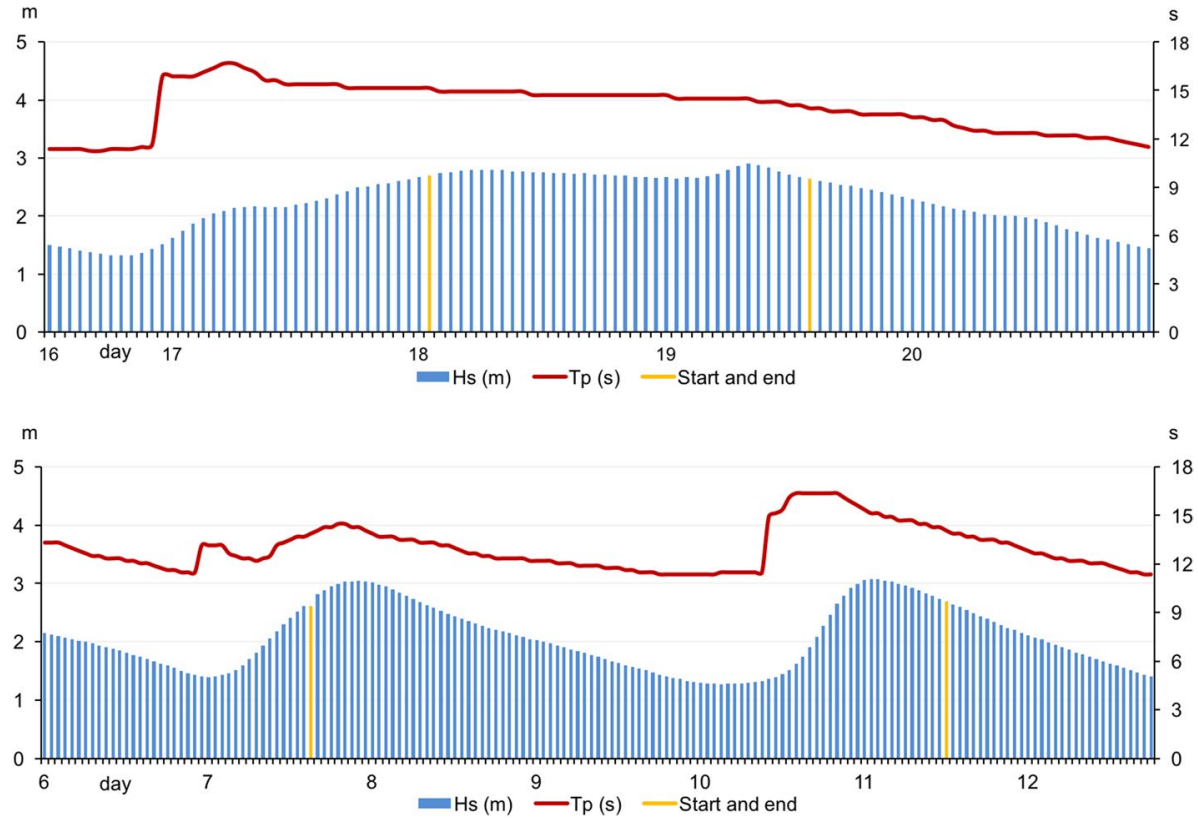

Fig. 4 Evolution of $H_{\mathrm{s}}$ and $T_{\mathrm{p}}$ in swell storms in Los Cristianos, Las Américas-Fañabé and Caleta de Adeje (SW of Tenerife). Upper graph: regular single episode (18-19/12/1972). Lower graph: irregular discontinuous episode. Source: State Ports (Spain)
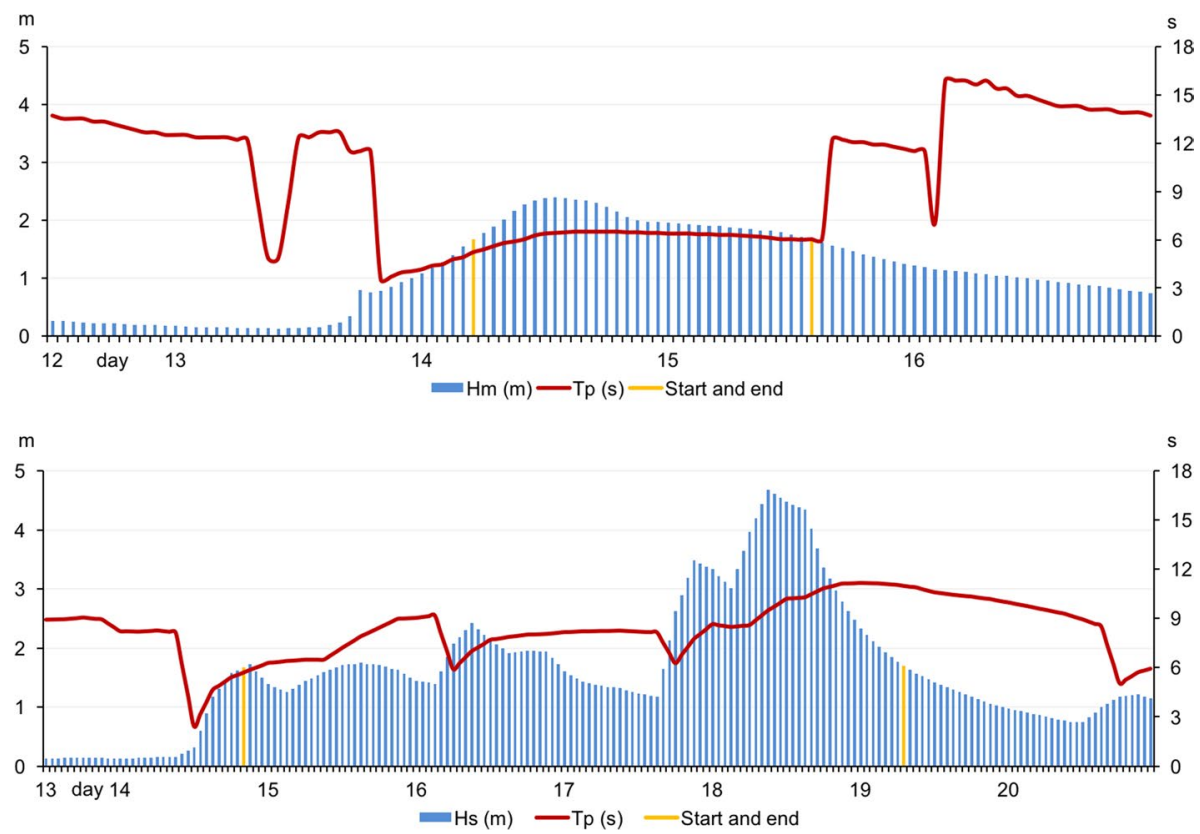

Fig. 5 Evolution of $H_{\mathrm{s}}$ and $T_{\mathrm{p}}$ in sea storms in Maspalomas, Anfi del Mar-Patalavaca and Puerto Rico-Amadores (S-SW of Gran Canaria). Upper graph: regular single episode (14-15/11/1968). Lower graph: irregular discontinuous episode (14-19/2/2010). Source: State Ports (Spain) 
height, respectively (S-SW Gran Canaria: 14-15/11/1968, 04-05/2/1976, 04-08/12/1991 and 26-29/11/2014). The waves of discontinuous events (37.9\%) are irregular, as a result of the fluctuations of the $H_{\mathrm{s}}$, which are more or less numerous and marked in the 1.5-4 days in which the majority occur (S-SW Gran Canaria: 16-21/1/1979, 02-03/2/1981, 05-07/1/2005 and 14-19/2/2010).

e. Energy content the application of the Storm Power Index (SPI) also reflects the specificity of the phenomenon investigated (Table 4). This index of potential damage reveals the predominance of low energy marine storms in the study area as a whole, since the average of the weak ones (class I) accounts for $43.9 \%$ of the recordings. These are followed according to their frequency by the moderate storms (class II 26.1\%), significant (class III 12.6\%), severe (class IV 11.9\%), and finally, extreme storms (class V 5.4\%). This is compensated, however, by a duration and an average SPI of 5.1 days and 2231.4, respectively, values that are smaller in the lower categories reaching 1.1 day and 172.5 of average SPI in the class I events.

The established classes differ when the different tourist centers are analyzed separately. The SPI (Fig. 6; Table 4) is higher in Los Cristianos, Las Américas-Fañabé and Caleta de Adeje than in Maspalomas, Anfi del Mar-Patalavaca and Puerto Rico-Amadores, because, before a 217.5 of class I and 2319.8 of class V in the SW of Tenerife, the values of each of them are 127.5 and 2142.9 in the S-SW of Gran Canaria. There is also a greater diversity of types of rough seas per year in the localities of Tenerife, since in $63.4 \%$ of the cases, events of two, three and even four classes are in the same year; on the contrary, in Gran Canaria uniformity prevails, since the storms that occur per year correspond in $46.7 \%$ of the times to a single class. This circumstance has changed, however, since 2010, as the number of storms of different categories per year has increased. Some of them stand out for their energy load, such as IV and V, compared to previous years. Another issue to study is the relevance of the severe and extreme storms in Los Cristianos, Las Américas-Fañabé and Caleta de Adeje. With an average of $4.2 \mathrm{~m}$ of $H_{\mathrm{s}}$ and $15.5 \mathrm{~s}$ of $T_{\mathrm{p}}$, they together total $25 \%$ of the events, while in Maspalomas, Anfi del Mar-Patalavaca and Puerto Rico-Amadores both are limited to $9.5 \%$ of the total. In the latter enclaves, on the contrary, the weak and moderate episodes stand out, with an average of $2.3 \mathrm{~m}$ of $H_{\mathrm{s}}$ and $8.7 \mathrm{~s}$ of $T_{\mathrm{p}}$, and they group together $82.5 \%$ of the events compared to $57.6 \%$ of the enclaves of Tenerife.

The similarities and differences are repeated on a monthly basis. The most significant of the former is the concentration in winter, not only of the most numerous events but of a smaller and larger scale. The territories of both islands register weak storms in this season, a quarter of the total of those that occurred, but also severe and extreme $(18.7 \%$ in the SW of Tenerife and $8.4 \%$ in the S-SW of Gran Canaria). Both appear in spring and autumn, although their impact is reduced. Regarding the latter, the distribution of storms in spring and autumn is relatively more homogeneous in Los Cristianos, Las AméricasFañabé and Caleta de Adeje than in Maspalomas, Anfi del Mar-Patalavaca and Puerto Rico-Amadores. In the former there are categories I to IV events with more or less similar values and in these the number is lower and their distribution is polarized around range I. This also applies to summer, a period in which extreme phenomena are limited to S-SW Gran Canaria.

f. Meteorological factors the examination of barometric situations allows the identification of different atmospheric configurations at the origin of the storms. Starting from 

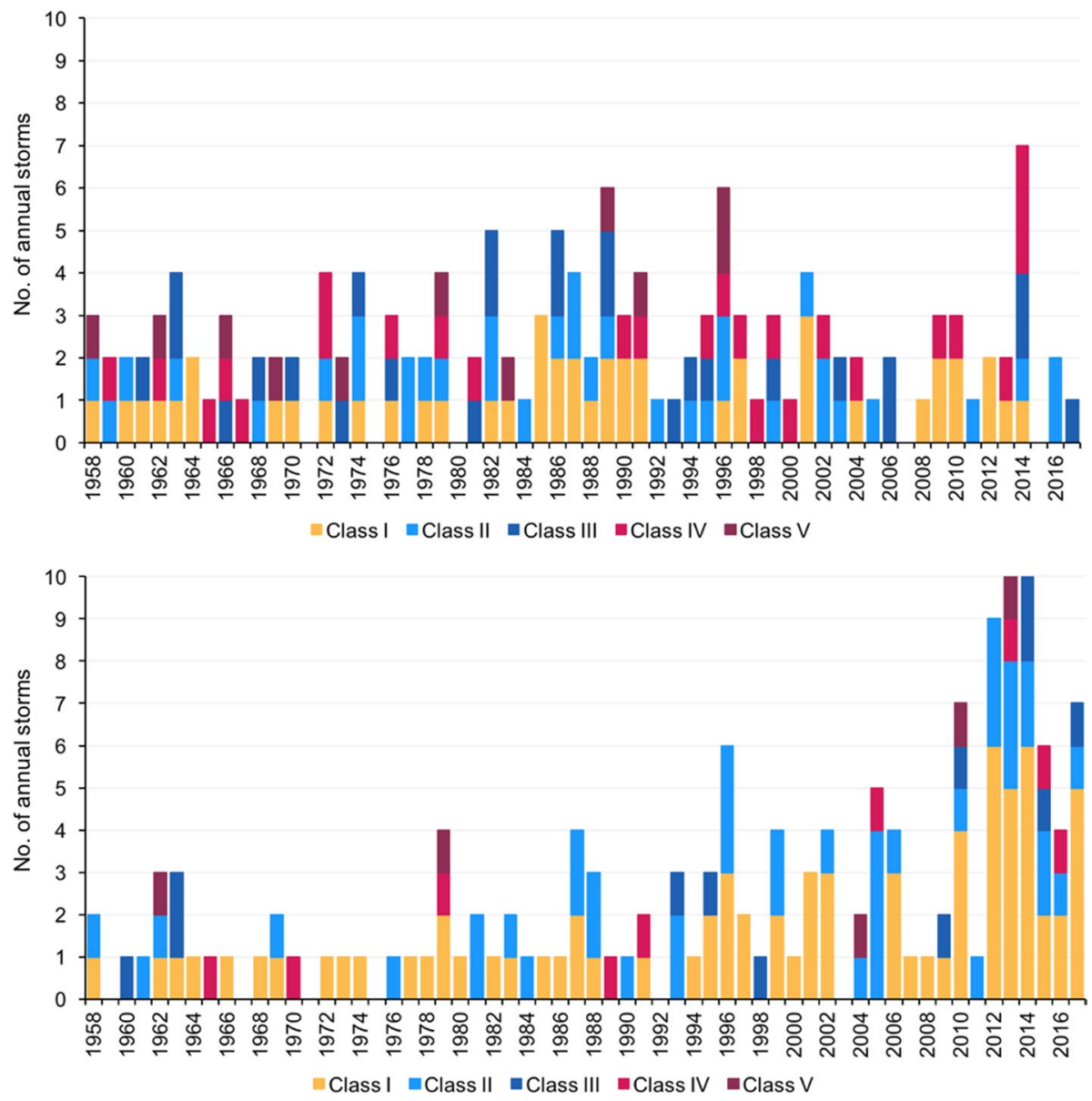

Fig. 6 Annual classification of marine storms according to their SPI in Los Cristianos, Las AméricasFañabé and Caleta de Adeje (SW of Tenerife) (upper graph) and Maspalomas, Anfi del Mar-Patalavaca and Puerto Rico-Amadores (S-SW Gran Canaria) (lower graph) (1958-2017). Source: State Ports (Spain)

a simple but effective classification, the relationship between rough seas and the state of the atmosphere indicates that the area of origin of the waves, which affects the tourist centers of Tenerife and Gran Canaria, is linked to five groups of types of weather. Depending on their nature and location (Fig. 7), these are anticyclonic situations (A), low pressures in the areas surrounding the Canary Islands (BC), low pressures in the Azores-Iberian Peninsula (BZ), low pressures above $45^{\circ} \mathrm{N}$ and $40^{\circ} \mathrm{W}$ (BA), mixed situations (M) and unclassified dates (N/A).

The analysis of such groups reflects their differing protagonisms, depending on whether the date of the storm or the affected localities is considered. In the first case, one in four stormy episodes is determined by anticyclonic conditions and the rest by atmospheric instability situations. In the second case, the notably different and opposed meteorological origin of the storms on both islands stands out (Table 5). 


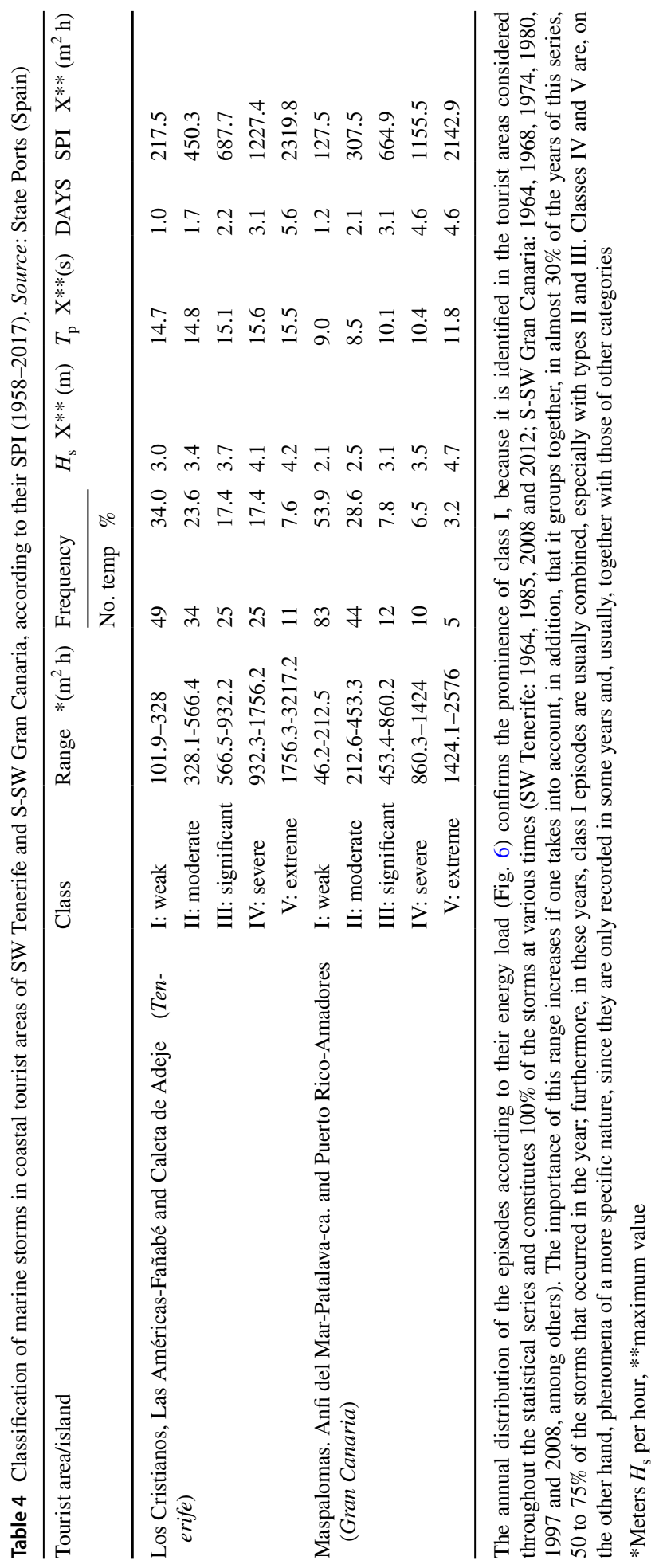




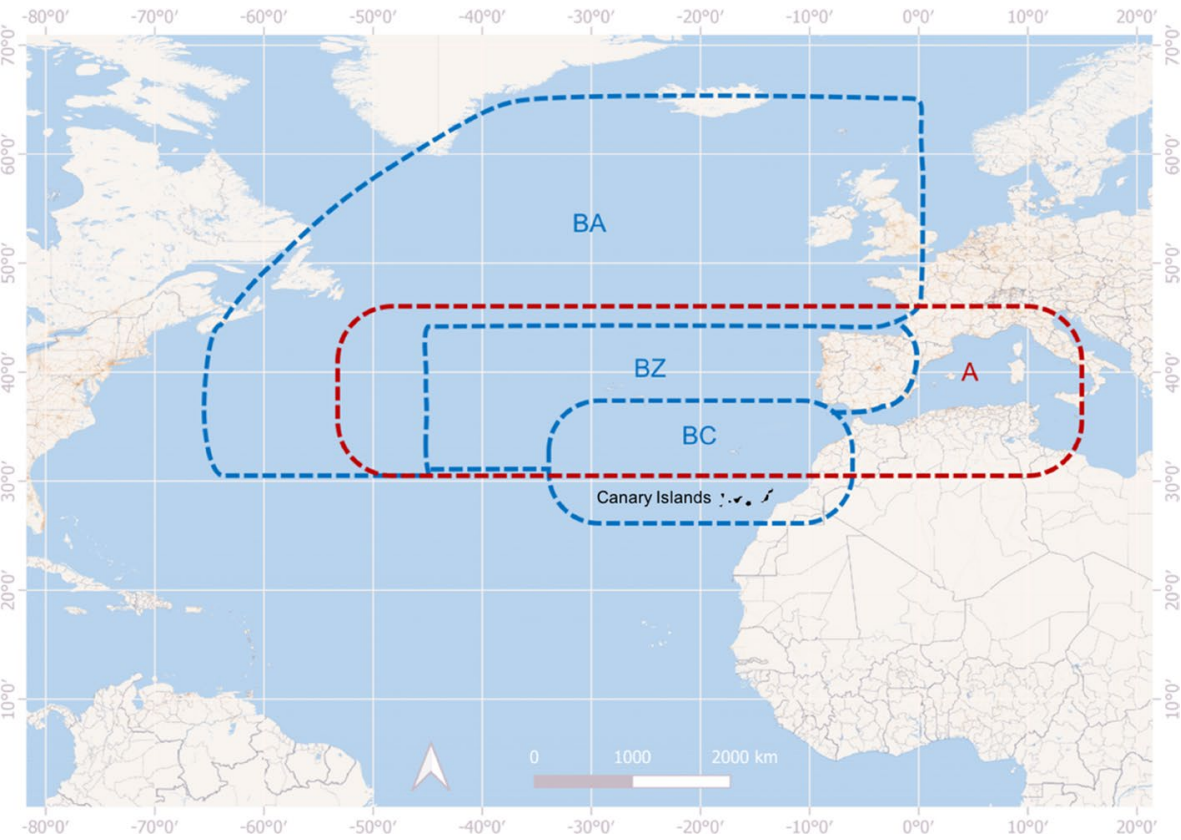

Fig. 7 Types and location of pressure centers generating marine storms in Los Cristianos, Las AméricasFañabé and Caleta de Adeje (SW of Tenerife) and Maspalomas, Anfi del Mar-Patalavaca and Puerto RicoAmadores (S-SW of Gran Canaria) (1958-2017)

Those that occurred in the SW of Tenerife are mostly swell episodes (87.7\%). They are linked to different depressive configurations (76.6\%) with a wide distribution in the Center and North of the Atlantic. Among them, the farthest from the Canary Islands region stand out due to their frequency (BA, 36.8\%). This favors a long fetch to the islands and, therefore, developed wave trains typical of a NW-N swell (Fig. 7). In this context, the storms
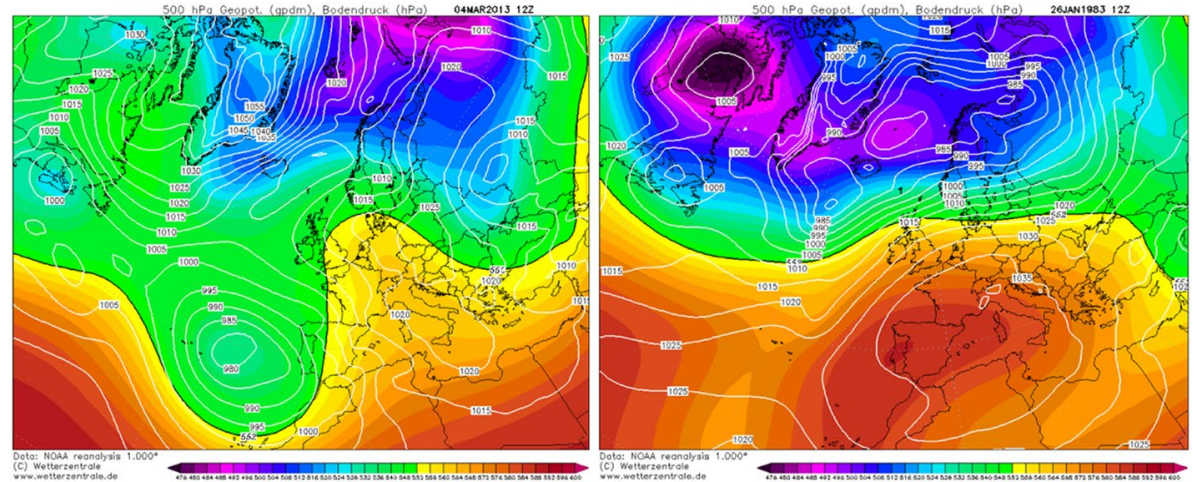

Fig. 8 Barometric situations typical of marine storms in the study area. Left picture: depression in AzoresIberian Peninsula-Canaries with a swell surge in the SW of Tenerife. Right picture: high pressure with a sea surge in the S-SW of Gran Canaria. Source: Wetterzentrale 
Table 5 Barometric origin and type of swell of sea storms in coastal tourist areas of SW Tenerife and S-SW Gran Canaria (1958-2017). Source: Wetterzentrale

\begin{tabular}{|c|c|c|c|c|c|c|c|c|}
\hline \multirow{3}{*}{$\begin{array}{l}\text { Tourist area/island } \\
\text { Atmospherical configuration }\end{array}$} & \multicolumn{4}{|c|}{$\begin{array}{l}\text { Los Cristianos, Las Américas- } \\
\text { Fañabé and Caleta de Adeje } \\
\text { (Tenerife) }\end{array}$} & \multicolumn{4}{|c|}{$\begin{array}{l}\text { Maspalomas, Anfi del Mar- } \\
\text { Patalavaca and Puerto Rico- } \\
\text { Amadores (Gran Canaria) }\end{array}$} \\
\hline & \multicolumn{8}{|c|}{ Type of swell (\%) } \\
\hline & Sea & Swell & Not clas. & Total & Sea & Swell & Not clas. & Total \\
\hline A (anticyclone situation) & 0.7 & 7.9 & 0.2 & 8.9 & 35.8 & 0.5 & 0.0 & 36.3 \\
\hline $\mathrm{BC}$ (low pressure around the Canaries) & 4.2 & 15.6 & 1.5 & 21.2 & 23.0 & 2.3 & 2.0 & 27.3 \\
\hline BZ (low pressure around the Azores) & 2.7 & 22.2 & 1.7 & 26.7 & 15.5 & 1.8 & 4.2 & 21.5 \\
\hline BA (low pressure above $45^{\circ} \mathrm{N}$ and $40^{\circ} \mathrm{W}$ ) & 0.3 & 36.8 & 0.3 & 37.3 & 7.0 & 2.8 & 1.0 & 10.8 \\
\hline M (mixed situation) & 0.0 & 2.0 & 0.5 & 2.5 & 1.0 & 0.0 & 0.3 & 1.3 \\
\hline N/D (not classified) & 0.3 & 3.2 & 0.0 & 3.5 & 2.3 & 0.5 & 0.2 & 3.0 \\
\hline TOTAL & 8.2 & 87.7 & 4.2 & 100 & 84.5 & 7.8 & 7.7 & 100 \\
\hline
\end{tabular}

associated with high pressure are minimal (7.9\%). These contrasts are repeated in sea events, although their presence in the total is small. In the S-SW of Gran Canaria, the situation is reversed due to the dominance of sea storms (84.5\%). They are linked to an anticyclonic configuration (35.8\%), the result of the location of high pressure in the Azores or of a zonal anticyclone with its center widely spread over the Iberian Peninsula. Winds and waves of the first and second quadrants are generated in both cases. A little more than $20 \%$ of the storms result, in addition, from depressive conditions with their nucleus located in the areas surrounding the Canary Islands (BC). This ultimately favors a short fetch. This opposition between the types of weather indicated is still maintained in swell events, despite their low representation in the total (7.8\%).

Figure 8 shows two examples of the composition of the atmosphere, which occurs in the storms under study. The map of March 4, 2013 (left image) corresponds to a low pressure situation (BZ), which favors a swell in the SW of Tenerife, while that of January 24, 1983 (right image) shows the dominance of the high pressures with moderate winds from the SE in the Canary Islands, with a storm of sea in the S-SW of Gran Canaria.

\subsection{Marine storm impacts}

The press has been reporting the effects of wave force in the study area since 1970 and there have been 217 stormy events to consider since then. However, there 18 direct allusions to some type of damage caused in those 217 storms (8.3\%). Figure 9 shows the relationship between marine storms, SPI and impacts caused. Those that occurred in the SW of Tenerife are shown by green dots, while the black ones correspond to those in the S-SW of Gran Canaria. The concentric circles that frame such points refer to episodes whose damage has been reported by the press. The red ones show those with serious consequences and the orange ones those with less serious effects. Finally, the number next to each circle shows the date when these episodes took place.

Of all the 217 storms, only 15\% coincide simultaneously in Tenerife and Gran Canaria and the news reports about damage in all of the selected tourist enclaves is limited to $1 \%$ of all the storms. This is the case of those on 16-21/1/1979, 04-07/12/1991 and $19-21 / 2 / 2004$, which are also the events causing the most damage in the study area. From 


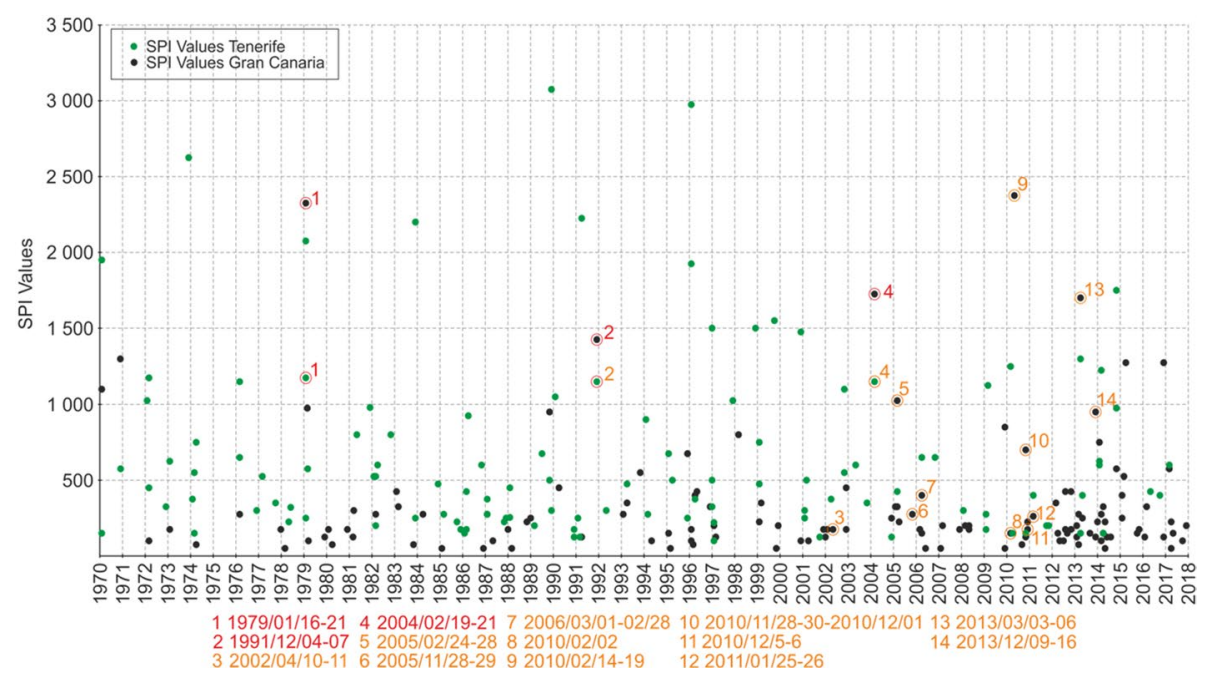

Fig. 9 Relationship between marine storms, SPI and damage, according to information in the press, in the SW of Tenerife and the S-SW of Gran Canaria (1970-2017)

the analysis of Fig. 9, it should also be noted that storms with a higher energy load do not cause the most substantial losses, given the lack of information in this regard in the newspapers. The situation regarding Tenerife is striking, because, although this island has the highest SPI storms (category V), most of the consequences of the waves are the result of less intense storms (categories II, III and IV). This last circumstance can be extrapolated only in part to Gran Canaria, because the episodes leading to damage are of weak to significant energy (categories I, II and III) in 50\% of the cases and from severe to extreme (categories IV and V) in the other $50 \%$.

The information on the impact on the coastline differs appreciably between tourist enclaves (Table 6). Press reports cover $7 \%$ of the storms in Tenerife, meaning that $93 \%$ of cases are not reported. On the contrary, 27, 32 and $62 \%$ of the news on the subject concerns Maspalomas, Anfi del Mar-Patalavaca and Puerto Rico-Amadores, respectively. The lack of reference to damage caused by storms in these locations ranges between almost 40 and $75 \%$. Regarding the type of damage, damage to beaches due to loss of sand and erosion, accumulation of waste and deterioration of equipment are the most frequent (32\%). They are closely followed by damage to marinas and commercial ports, related to the sinking of boats and inoperative port services (30\%). Somewhat less are damage to dykes and breakwaters (14\%) and the flooding of tourist accommodation and commercial and service areas (12\%). Finally, the loss of life due to drowning and the rescue of bathers and missing persons account for up to $10 \%$ and only $1 \%$ refers to the evacuation of tourists from accommodation damaged by the waves.

The relationship between the nature of the damage and the type of seafront shows that $62 \%$ of this is concentrated on artificial coastlines. This mainly occurs in Los Cristianos, Las Américas-Fañabé (SW Tenerife) and Puerto Rico-Amadores (S-SW Gran Canaria), relating to damage in marinas and commercial ports (35\% of the total damage) and promenades $(21 \%)$ and flooding of tourist accommodation, commercial areas and service areas (18\%). Added to this is the breaking of sheltered dykes (11\%), the erosion of artificial beaches (9\%) and, to a lesser extent, the evacuation of tourists $(6 \%)$. 
Thirty-eight per cent of the remaining damage occurs on natural coasts, such as the beaches of Maspalomas and El Inglés (S-SW Gran Canaria), where half is related to the movement of sand, the cliffing of dunes or the flooding of interdune depressions (Fig. 10) and a third result from loss of life, disappearance and rescue of bathers. The accumulation of waste on the beaches (18\%) and the flooding of commercial areas and hotels near the mouths of the ravines (3\%) are also confirmed consequences on these coasts.

Although the economic valuation of the repercussions of storms is of great interest in the study of the damage caused, there are few explicit references to this in the press. In the tourist centers in Tenerife, these are limited to the storm on 16-18/1/1979, which caused $€ 4,253,483$ (as of January 2020) of losses due to the breakage of $150 \mathrm{~m}$ of the Puerto de Los Cristianos protection dam (Diario de Avisos, 18/1/1979, page 1). In Gran Canaria, information has been found on the damage by the storm on 04-07/12/1991 (Máyer 2011). This damage was reported to be $€ 4,932,347$ (as of January 2020), according to the damage reports that the municipalities sent to the civil protection headquarters of the Government delegation in the Canary Islands.
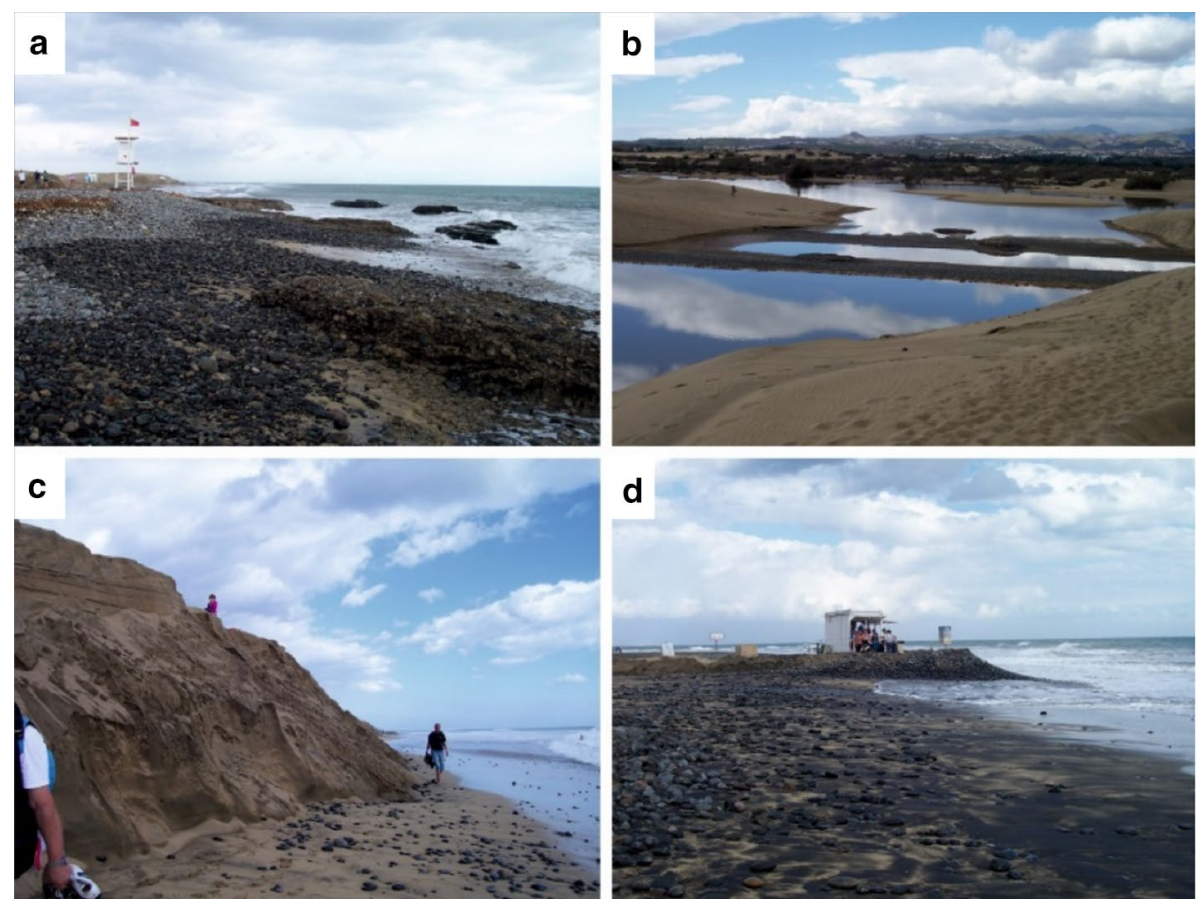

Fig. 10 Consequences of the marine storm on 28/II-01/III/2006 on the beach of Maspalomas (S-SW of Gran Canaria): a loss of sand and outcrop of the beachrock constituting the original rocky substrate; b flooding of interdune depressions; c cliffing of dunes and $\mathbf{d}$ erosion of the beach and damage to its facilities. Author: Hernández-Calvento, L (2006) 


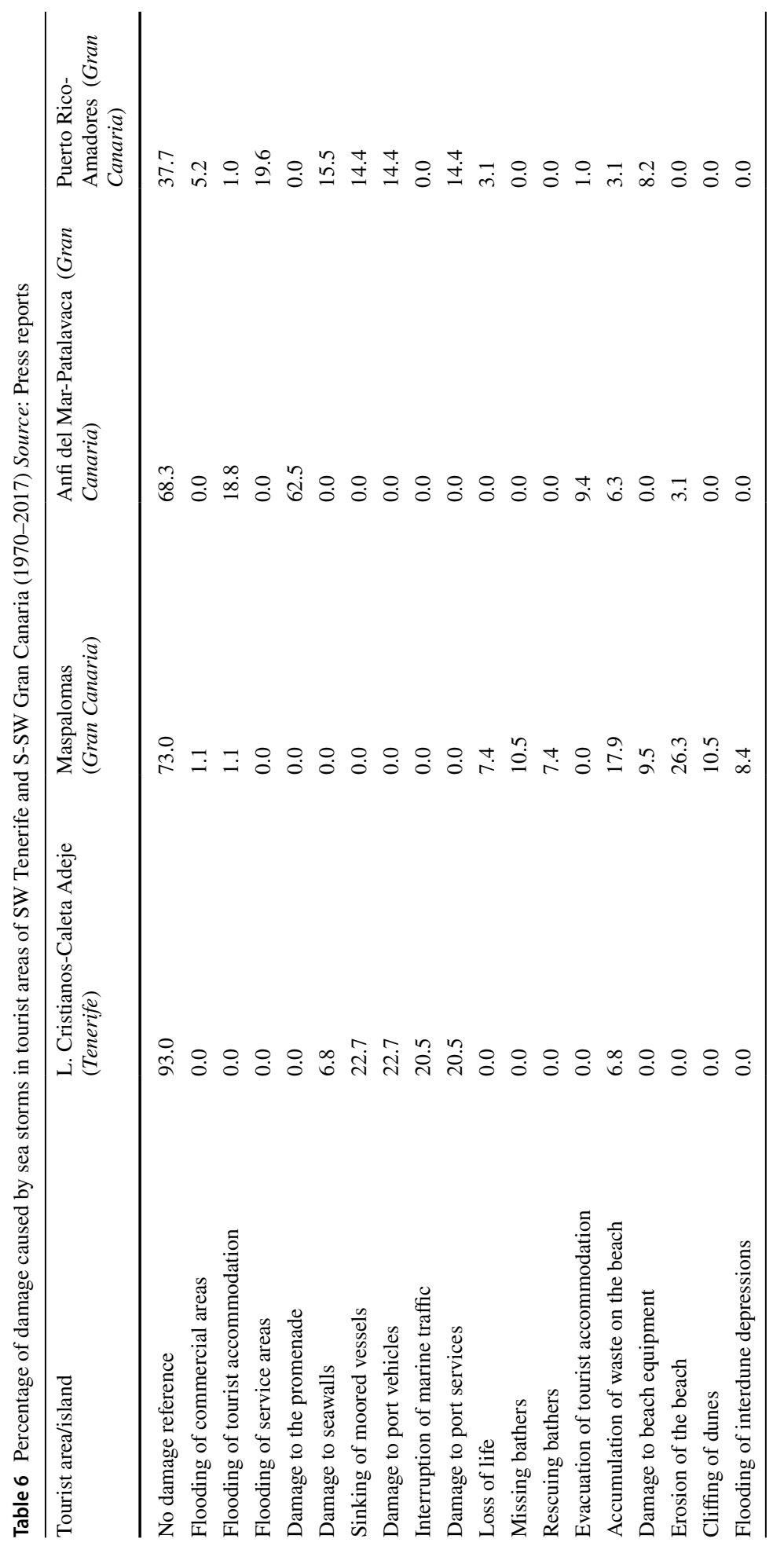




\section{Discussion}

The analysis here shows the disturbing effect that marine storms have on the study area. This is because the area in question is a narrow strip with an intensive, rapid and poorly adapted urbanization, aimed at meeting the demand for leisure by the sea. The concentration of a large part of the tourist activity and employment of Tenerife and Gran Canaria in this area makes it a space which is sensitive to the impacts of adverse marine phenomena, which take place in an area dominated, in general terms, by moderate waves; specifically, for a sea from the NNE-NE, linked to trade winds of $15-20 \mathrm{~km} / \mathrm{h}$ in response to the presence of the Azores Anticyclone in the area of the Canary Islands, during most of the year. However, other more energetic waves act on this coast, originating in the North Atlantic. This occurs, especially in winter, when the pressure center moves in latitude and/or in longitude. This facilitates the arrival of a swell from the NNW, with waves of greater height, period and length. These can lead to rough seas, the result of a marked atmospheric instability in northern latitudes.

This circumstance is relevant in the SW of Tenerife. Its location on a slope facing the open ocean and in a poorly sheltered environment explains the predominance of the winter swell (Losada et al. 2014). Its relationship with low pressure centers in the temperate zone with trajectories towards increasingly southern latitudes should be considered (Menéndez et al. 2014; Cid et al. 2016). With a N-S route, they reach this coast passing through the west of the archipelago or channeling between the east of La Palma and the west of Tenerife to end up rolling towards the SE. They are responsible for the strong superelevated waves of the fourth quadrant, which presumably retain part of their initial energy as they approach the shore. This is so considering the narrowness and rocky character of the littoral platform, which would limit the refraction of the waves, in a context made up of recent Aa lava fields with lavas that penetrate the sea (Kereszturi et al. 2013).

The lower incidence of the swell in the S-SW of Gran Canaria can be related to the protection that the interposition of Tenerife, La Gomera and El Hierro provides between Gran Canaria and the Atlantic Ocean (Losada et al. 2014); and, also, with a certain loss of the initial force of the waves when advancing on a broader and sandy coastal platform, associated, at least in some sectors, with old alluvial fans formed in ravines of a certain size (Klug and Raeth 1989). Hence, the primacy of poorly developed local waves from the first and third quadrants, is sometimes linked to the location of depressive centers on the vertical of the Canary Islands or in its vicinity and others to an anticyclonic configuration. In any case, it is worth highlighting the notoriety that the storms have acquired, especially in the second decade of the twenty-first century. Although there were hardly any long-term variations in the episodes of cyclonic storms in the European South Atlantic, it is possible that a period of high frequency of anticyclonic situations has occurred (Menéndez et al. 2014; Cid et al. 2016). This would explain the increase in sea storms in Gran Canaria. They may also be related, on the other hand, to the large number of winters with positive NAO and dry years in general in the Canary Islands, due to the predominance of atmospheric stability (Dorta and López-Díez 2020).

The characterization of the marine storms here also shows that the impacts of the waves vary in time and space. The fact that the damage caused was not found in the press until the $1970 \mathrm{~s}$ is related to the reduced transformation of the coastal area in those years. It should be noted that the storms that occurred previously in the study area did not attract media interest, because they did not cause damage or were of little scope; in the same way, it should be considered that the information did not circulate at that time with the immediacy 
with which it does today and that the tourist locations considered were far from the capitals of each island. In addition, many effects of the waves that are taken into account today, in the event of the loss of sand from the beach, might not have been perceived as a problem at that time. In this respect, the use of the beach was testimonial in an agrarian-based economy; consequently, such effects are not mentioned in the press reports.

Although the news about losses has gradually increased, the number and coverage differ from one tourist center to another and according to the newspaper in question, due to the high local component of the news. An examination of the press reports shows that information in Tenerife about the bad state of the sea tends to remain in the background. This is perhaps due to the associated social repercussions of the rain and wind episodes and because the reports of maritime storms are limited to the possibility of adverse coastal phenomena occurring, when the meteorological warnings are issued. Lastly, the fact that the most significant consequences are the sinking of vessels in the port, the interruption of maritime traffic and the deterioration of port services may reduce the notoriety of the wave force, as it does not have a direct impact on spaces of a more touristic use such as promenades and beaches. As for Gran Canaria, it is possible that the greater attention paid to marine storms is because of the interest aroused by the rescue, disappearance and death of bathers. The concern about the economic damage caused by the loss of sand, the deterioration of beach equipment, the breakage of promenades and the flooding of tourist accommodation is because this has also attracted attention in recent years.

Regardless of the number of references, the truth is that the press information shows that the strongest and most extraordinary storms (category V) are not the cause of the greatest damage. This damage is due to waves of less intensity, since those are bound, by their own parameters, to break at a certain distance from the coast (Sanjaume 1985); They are also usually discontinuous episodes in which the height of the $H_{\mathrm{s}}$ is lower at times than the extreme wave identification threshold. It should be taken into account, in the same way, that the ravages of the sea can result from the action of a storm preceded by others in a more or less short period of time and whose repetition has gradually reduced the resistance of the coastline to the action of the waves. Fundamentally, this is about assessing their cumulative impact (Ferreira 2006; Menéndez et al. 2014; Garmendia et al. 2017). The recording of 4 storms on both islands in 1987 and 1991 is in line with this; from 6 to 1996 and as high as 9 in Gran Canaria in 2012.

The stormy phenomenon on 04-07/12/1991 illustrates the changes in the state of the sea and the exposure and vulnerability of the coasts analyzed here, greatly transformed by tourist activity, in light of the notable losses suffered. Figure 11 shows that it is during a 3.7-day episode when the $H_{\mathrm{s}}$ and Hmax rise both sharply and markedly. The former and the latter rise from 0.5 to $1.7 \mathrm{~m}$ and from 1.1 to $2.8 \mathrm{~m}$, respectively, in the five hours prior to the start of the storm; at the same time, the $T_{\mathrm{p}}$, typical of a swell, falls ostensibly to around 4-4.5 s.

Figure 11 Evolution of the $H_{\mathrm{s}}$ and $T_{\mathrm{p}}$ of the marine storm of 04-07/12/1991 affecting the coastal tourist areas of the SW of Tenerife and S-SW of Gran Canaria.

These variations have their origin in a marked atmospheric instability caused by a deep trough, whose nucleus is located on December 3 in the vicinity of Newfoundland (Fig. 12). Its movement to the east affects the Canary Islands on the 4th and from the 5th a DANA is picked up and individualized, which remains active until the 7th of the same month.

The above evolution generates a storm of abundant rains, especially in the south of the islands $(60 \mathrm{~mm}$ at the Tenerife-South airport) and strong winds from the $\mathrm{W}$ and $\mathrm{SW}$ of $75-80 \mathrm{~km} / \mathrm{h}$. These flows, the result of the depression itself located in the vertical of Madeira, with a minimum surface pressure of $990 \mathrm{hPa}$, determine an energetic sea. This 


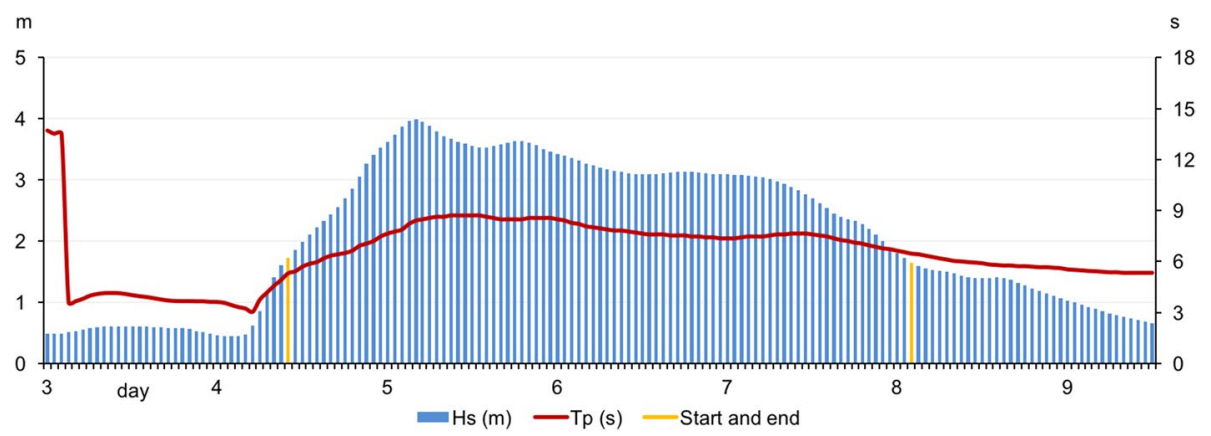

Fig. 11 Evolution of the $H_{\mathrm{s}}$ and $T_{\mathrm{p}}$ of the marine storm of 04-07/12/1991 affecting the coastal tourist areas of the SW of Tenerife and S-SW of Gran Canaria
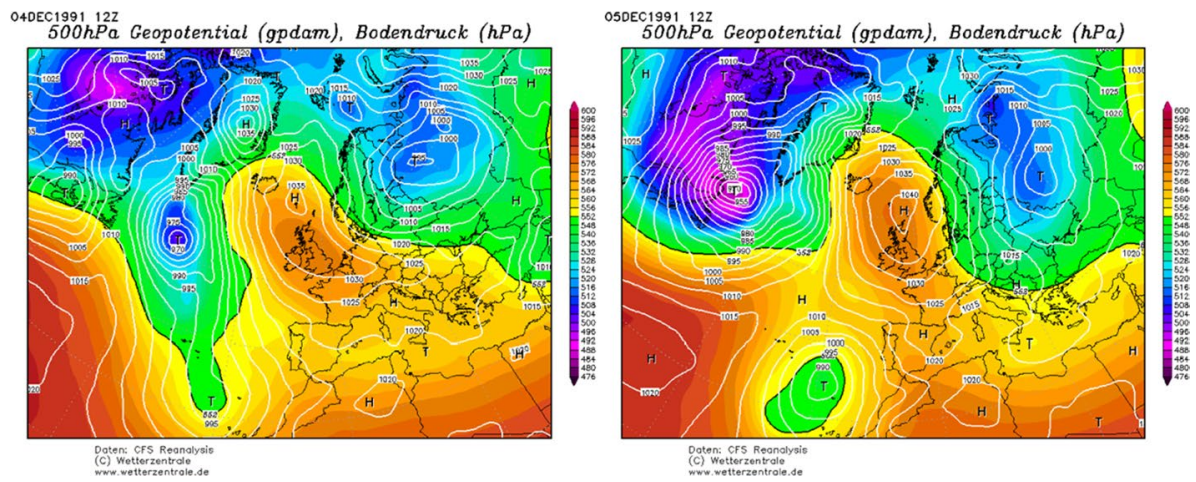

Fig. 12 Atmospheric configuration causing the marine storm of 04-07/12/1991. Left image: situation corresponding to December 4. Right image: situation corresponding to December 5. Source: Wetterzentrale

presents a $H_{\mathrm{s}}$ of $3.0 \mathrm{~m}$ of average height, which reaches a maximum value of $4.0 \mathrm{~m}$ in the center of the storm. This occurs in the transit from high tide of $2.06 \mathrm{~m}$ at $11: 54 \mathrm{a} . \mathrm{m}$. on December 4 to low tide of $0.47 \mathrm{~m}$ at 05:45 a.m. on day 5 (Diario de Avisos, page 74). In this period of time, the $H_{\max }$ reaches $6.8 \mathrm{~m}$ (Fig. 11). Furthermore, it is possible that the development of the storm may coincide with a rise in sea level due to the effect of the meteorological tide, which in the Canary Islands is usually, on average, $20 \mathrm{~cm}$ (Losada et al. 2014). In any case, they are waves from the third quadrant with a small $T_{\mathrm{p}}$ and $L$, because they are on average $7.6 \mathrm{~s}$ and $90.1 \mathrm{~m}$, respectively. These features are maintained with certain fluctuations until the middle of the 7 th, when the different parameters gradually decrease until the end of the storm, in the early hours of December 8 .

There are multiple consequences of the agitation of the sea in the study area, particularly in the SW of Gran Canaria. The damage is numerous in the infrastructures of the Puerto Rico dock (Fig. 13), in relation to the destruction of the dykes and breakwaters of its outer dock, jetties for mooring boats and different water and electricity supply networks; likewise, there is damage to the promenades, dykes and breakwaters of Anfi del Mar and Patalavaca. In both centers, the waves also affect the mouth of ravines and accumulate waste on various beaches, while harming their services (sunbeds, water skiing, motor boating ...). 

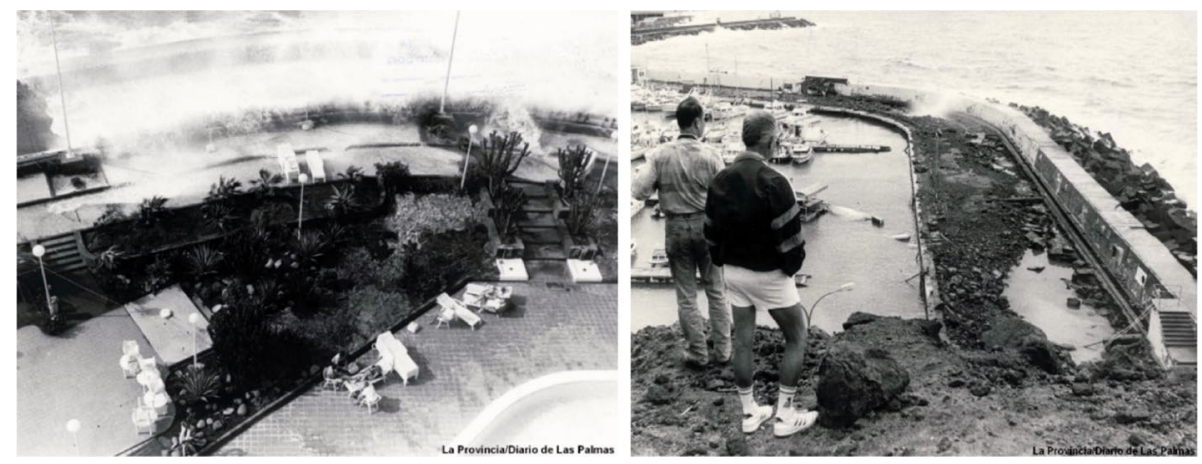

Fig. 13 Overtopping (left image) and swell effects (right image) in the Green Beach tourist complex (Puerto Rico, SW Gran Canaria), resulting from the marine storm on 04-07/12/1991. Source: La ProvinciaDiario de Las Palmas (07/12/1991)

The damage is less important in other enclaves. This is the case of Maspalomas, where it is limited to the floods produced by the heavy rains in one of its shopping centers and the dragging of material to the mouth of the ravine of the same name, as a result of the torrential flow of water caused by these rains; this is also the case in Los Cristianos (SW of Tenerife), an enclave where the only problems are caused by the interruption of maritime communications between islands and the sinking or stranding of various vessels.

Table 7 shows the characteristics of the damage, the type of spaces and infrastructures affected and the amount thereof, based on the calculations made by local administrations. Although the available data differ according to localities, the overall amount of the losses is noteworthy. The amount of $€ 4,932,347.15$ (as of January 2020) shows the severity of the episode analyzed.

\section{Conclusions}

The analysis performed here shows the high degree of exposure of the coastal tourist enclaves of the SW of Tenerife and S-SW of Gran Canaria to the impacts of the waves, as their coastline has seen an incessant growth of urbanization. This results in a high density of building parallel to the shore, which favors the disturbance of these enclaves by destructive physical processes. This is the case of marine storms, which require greater and better knowledge as, especially since the beginning of this century, it has been among the meteorological phenomena causing the most fatalities in Spain (17\%), after heat waves $(28 \%)$ and floods due to heavy rains (20\%) (Ministry of the Interior 2019).

The marine storms recorded in the study area occur in an area with defined atmospheric patterns. These result from fluctuations in the pressure gradient between the Icelandic depressive nuclei and the Azores anticyclone, particularly during winter. The greater or lesser intensification of this gradient in the North Atlantic translates into a variable affectation of the coast by swells that increase their energy. This does so to the point that the maximum height of the $H_{\mathrm{s}}$ exceeds its usual value between four and fivefold. This implies a notable danger, not always well assessed, due to the moderate annual average wave regime in the study area. 


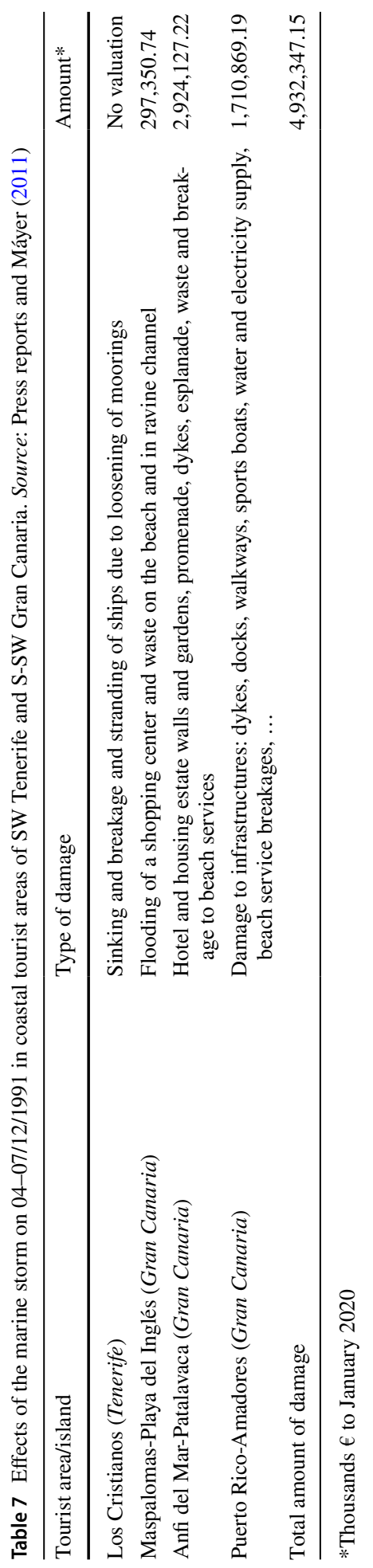


The marine storms examined correspond to specific patterns, depending on their features and affected coastline. These are, on the one hand, highly developed swell episodes and regular behavior coming from the North Atlantic. Their prevalence is notable in the SW of Tenerife (88.2\%), where the SPI of up to $25 \%$ of the events is severe to extreme; There are, on the other hand, episodes of sea of variable power and irregular behavior, the result of situations of atmospheric instability between the Canary Islands and the Azores. They are felt, especially in the S-SW of Gran Canaria (85.7\%), on whose coast the SPI oscillates between weak events $(53.9 \%)$ and severe and extreme $(9.7 \%)$. The contrasts of both patterns are linked, to a certain extent, to the "screen effect" that some islands of the archipelago exert on extreme waves. This occurs in the SW of Tenerife, up to $86.1 \%$ of its storms in the fourth quadrant, which on their way to the island can be channeled between La Palma, La Gomera and El Hierro. Tenerife forms, for its part, an obstacle with respect to the storms affecting the S-SW of Gran Canaria. However, 55.8\% of them are from the third quadrant, with directions hardly hindered in their advance towards the coast of this island. In any case, $37.7 \%$ of the storms registered reached the study area in Gran Canaria from the first quadrant. In these circumstances, waves can experience a certain diffraction imposed by the island's configuration itself.

In this context, it is worth mentioning the publication, in 2006, of the Meteoalerta Plan by the State Meteorological Agency (AEMET), to standardize meteorological warnings within the European framework of such warnings (Meteoalarm) and optimize the requirements of society and civil protection authorities on them. In coordination with the Canary Islands Civil Protection Plans, their ultimate goal is to provide the best and most up-todate information possible on adverse atmospheric phenomena, by means of a color code (Elizaga 2009). Since the above year, the newspapers used in this work have incorporated the meteorological warnings issued by the AEMET, whether or not damage occurs on the coast.

Regarding the repercussions of marine storms on the socio-economic organization and natural systems of the study area, these differ depending on events and locations. In the first case, only $8.3 \%$ of these have a correlation in the press, insofar as this refers to the damage caused; it should be added that the episodes with very serious consequences are limited to three (16-21/1/1979, 04-07/12/1991 and 19-21/2/2004), depending on the news in the newspapers and the valuation of losses, when this information has been obtained. In the second case, because all the tourist centers considered are affected simultaneously by only $1 \%$ of the storms. It is significant that the references to damage are only $7 \%$ on the SW coast of Tenerife, with the coastline affected in the S-SW of Gran Canaria being from 27 to $62 \%$ depending on its enclaves. In any case, the greatest economic cost corresponds to breakage of dykes and breakwaters in the marinas and commercial ports and those that protect tourist establishments, especially when one has been flooded. It is also worth mentioning the damage to the promenades that connect them to the beaches, where loss of sand and erosion, the accumulation of waste and the deterioration of equipment are frequent. The incidence of such alterations is difficult to assess, because tourists continue to access the beach. They do so, even if the accumulation of waste prevents the occupation of any of its parts or the use of a service is temporarily interrupted. In addition, the coastline itself "rebuilds" the eroded sectors after months.

These aspects show the impact of the anthropogenic activity on the coastal environment on these islands caused by the frequent occupation of the maritime-terrestrial demarcation areas. For this reason, storms are felt, sometimes harshly, on the promenades, hotels and apartments built in these areas, as well as on docks and marinas. In the context of current global change, the reorientation of tourism towards coastal sustainability is a priority. 
Adequate planning and spatial planning are key issues, considering the many future projects that are to be carried out. Examples of these are, for example, the proposals to be executed at the mouth of the Balito ravine, in the vicinity of Anfi del Mar, a low-capacity marina that includes seasonal services (restaurant, kiosk, sports area ...); to install a restaurant in Patalavaca on the current coastal protection dyke and to expand the pier located next to the lighthouse in Maspalomas for mooring sports boats. Various public and private organizations have opposed these, following the information that appeared in the press, which shows their concern about the necessary preservation and conservation of the coastline. It is, thus, a new attitude of society, faced with the strong pressure and speculation exerted on coastal areas by developers eager to obtain maximum profits. And this without taking into account, among other aspects, the aftermath of marine storms, as explained in this work. The use of the information presented here could be useful to continue in the line of research addressed in the article.

Acknowledgements This research was funded by the Canary Government and the European Regional Development Fund (ERDF) to develop the research project "Flood impact analysis in coastal tourist areas: the Canary Islands. A natural laboratory of resilience"-ProId201710027-.

Funding Open Access funding provided thanks to the CRUE-CSIC agreement with Springer Nature.

\section{Declarations}

Conflict of interest The authors declare that they have no competing interests.

Open Access This article is licensed under a Creative Commons Attribution 4.0 International License, which permits use, sharing, adaptation, distribution and reproduction in any medium or format, as long as you give appropriate credit to the original author(s) and the source, provide a link to the Creative Commons licence, and indicate if changes were made. The images or other third party material in this article are included in the article's Creative Commons licence, unless indicated otherwise in a credit line to the material. If material is not included in the article's Creative Commons licence and your intended use is not permitted by statutory regulation or exceeds the permitted use, you will need to obtain permission directly from the copyright holder. To view a copy of this licence, visit http://creativecommons.org/licenses/by/4.0/.

\section{References}

Agencia Estatal de Meteorología (AEMET) (2006) http://www.aemet.es/es/noticias/2006/07/20060712

Afonso JA (2011) Canarias y los eventos extremos en el mar. Boletín de la Real Sociedad Económica de Amigos del País de Tenerife, Memoria 2010: 63-114

Almeida LP, Ferreira O, Vousdoukas MI, Dodet G (2011) Historical variation and trends in storminess along the Portuguese South Coast. Nat Hazards Earth Syst Sci 11:2407-2417. https://doi.org/10.5194/ nhess-11-2407-2011

Anfuso G, Rangel-Buitrago NR, Cortés-Useche C, Iglesias-Castillo B, Gracia FJ (2015) Characterization of storm events along the Gulf of Cadiz (eastern central Atlantic Ocean). Int J Climatol 36:3690-3707

Benavente J, Del Río L, Gracia FJ (2009) Riesgos litorales. Enseñanza de las Ciencias de la Tierra 17(3):277-283

Carreño M, Cardona OD, Barbat A (2002) Sistema de indicadores para la evaluación de riesgos. Centre Internacional de Mètodes Numèrics en Enginyeria (CIMNE), Barcelona

Cid A, Menéndez M, Castanedo S, Abascal AJ, Menéndez FJ, Medina R (2016) Long-term changes in the frequency, intensity and duration of extreme storm surge events in southern Europe. Clim Dyn 46:1503-1516. https://doi.org/10.1007/s00382-015-2659-1

Costas S, Ferreira O, Martinez G (2015) Why do we decide to live with risk at the coast? Ocean Coastal Manag 118:1-11. https://doi.org/10.1016/j.ocecoaman.2015.05.015 
Del Río L, Plomaritis T, Benavente J, Valladares M, Ribera P (2012) Establishing storm thresholds for the Spanish Gulf of Cádiz coast. Geomorphology 143-144:13-23

Dolan R, Davis RE (1992) An intensity scale for Atlantic coast northeast storms. J Coast Res 8:352-364

Dorta P, López-Díez A (2020) Cambio climático ¿Realidad o ficción? Las islas, En Hernández González F (dir) El derecho ante el reto del cambio climático. Pamplona, Thomson Reuters Aranzadi, págs. $81-110$

Eichentopf S, Karunarathna H, Alsina J (2019) Morphodynamics of Sandy beach under the influence of storm sequences: current research status and future needs. Water Sci Eng 12(39):221-234

Elizaga F (2009) Fenómenos adversos, prioridad básica de AEMET. Ambienta La revista del Ministerio de Medio Ambiente 85:29-35

Escartín FJ (2016) Gestión integrada del borde costero. Algunas experiencias en el litoral español. VII Seminario Internacional de Ingeniería y Operación Portuaria. Universidad de Valparaíso, Chile

Exceltur (2019) Impactur Canarias 2018. Estudio del impacto económico del turismo sobre la economía y el empleo de las Islas Canarias. Santa Cruz de Tenerife, Exceltur y Gobierno de Canarias https:// www.exceltur.org/wp-content/uploads/2019/12/IMPACTUR-Canarias-2018.pdf Consulta realizada el 23/09/2020

Ferreira O (2006) The role of storm groups in the erosion of sandy coasts. Earth Surf Process Landforms 31:1058-1061. www.interscience.wiley.com

Ferrer-Valero N, Hernández-Calvento L, Hernández-Cordero A (2017) Human impacts quantification on the coastal landforms of Gran Canaria Island (Canary Islands). Geomorphology 286:58-67

García-Romero L, Hernández-Cordero AL, Fernández-Cabrera E, Peña Alonso C, Hernández-Calvento L, Pérez-Chacón E (2016) Urban touristic impacts on the aeolian sedimentary systems of the Canary Islands: conflict between development and conservation. Isl Stud J 11(1):91-112

Garmendia Pedraja C, Rasilla Álvarez D, Rivas Mantecón V (2017) Distribución espacial de los daños producidos por los temporales del invierno 2014 en la costa norte de España: peligrosidad, vulnerabilidad y exposición. Estudios Geográficos LXXVIII(282):71-104

Hernández-Calvento L (2006) Diagnóstico sobre la Evolución del Sistema de Dunas de Maspalomas (19602000) [Diagnosis of Evolution Dunefield of Maspalomas (1960-2000)]. Las Palmas de Gran Canaria: Cabildo de Gran Canaria

Hernández-Cordero AI, Hernández-Calvento L, Pérez-Chacón Espino E (2017) Vegetation changes as an indicator of impact from tourist development in an arid transgressive coastal dune field. Land Use Policy 64:479-491

IPCC (2013) Climate change 2013: the physical science basis. In: Stocker TF, Qin D, Plattner G-K, Tignor M, Allen SK, Boschung J, Nauels A, Xia Y, Bex V, Midgley PM (eds) Contribution of working group I to the fifth assessment report of the intergovernmental panel on climate change. Cambridge University Press, Cambridge

IPCC (2014) Small islands. In: En Nurse LA, McLean RF Agard J, Briguglio LP, Duvat-Magnan V, Pelesikoti N, Tompkins E, Webb A (eds) Climate change 2014: impacts, adaptation, and vulnerability. Cambridge University Press, Cambridge, pp 1613-1654

Instituto Estadístico de Canarias (ISTAC) (2019) http://www.gobiernodecanarias.org/istac/

ISTAC (2020) Canary Statistics Institute. Canary Islands Government

Jackson NL, Nordstrom KF, Elliot I, Masselink G (2002) 'Low energy' sandy beaches in marine and estuarine environments: a review. Geomorphology 48:147-162

Kereszturi G, Geyer A, Martí J, Németh K, Dóniz-Páez J (2013) Evaluation of morphometry-based dating of monogenetic volcanoes-a case study from Bandas del Sur, Tenerife (Canary Islands). Bull Volcanol 75(734):1-19

Klug H, Raeth A (1989) Geomorphologische untersuchunger zur reliefgestal des schelfs und seiner beziehung zum formen charakter der küsten Gran Canaria (Kanarische Inseln). Essener Geogr 17:177-202

Ley 2/2013, de 29 de mayo, de protección y uso sostenible del litoral y de modificación de la Ley 22/1988, de 28 de julio, de Costas

Losada I, Izaguirre C, Diaz P (2014) Cambio climático en la costa española. Madrid. Oficina Española de Cambio Climático, Ministerio de Agricultura, Alimentación y Medio Ambiente

Macías-González FJ (2017) La problemática ambiental de urbanizaciones turísticas costeras: el ejemplo de Puerto Rico-Amadores, Gran Canaria (España). Tesis doctoral. Universidad de Las Palmas de Gran Canaria. https://accedacris.ulpgc.es/handle/10553/54052

Máyer P (1999) Un siglo de temporales en la prensa de Gran Canaria. Vegueta 4:267-282

Máyer P (2011) Lluvias e inundaciones en Gran Canaria, Islas Canarias, España. Editorial Académica Española, Madrid

Mendoza E, Jiménez J (2008) Clasificación de tormentas costeras para el litoral catalán (Mediterráneo NO). Ingeniería Hidráulica en México XXIII(2):21-32 
Menéndez García M, Pérez-García J, Méndez Icera FJ, Izaguirre Lasa C (2012) Cambios en los eventos extremos de inundación en la costa. VIII Congreso Internacional de la Asociación Española de Climatología, Universidad de Cantabria, pp 529-538

Menéndez M, Espejo A, Pérez J, Méndez FJ, Losada IJ (2014) Análisis climatológico de los temporales marítimos en la cornisa atlántica durante el invierno 2013-2014. Publicaciones de la Asociación Española de Climatología serie A 9:489-498

Ministerio del Interior (2019) Anuario estadístico 2019. Subdirección General de Planificación, Operaciones y Emergencias. Dirección General de Protección Civil y Emergencias. Ministerio del Interior, Madrid

Molina R, Manno G, Lo Re C, Anfuso G, Ciraolo G (2019) Storm energy flux characterization along the Mediterranean costa of Andalusia (Spain). Water 11, 509: 1 of 14

Ministerio de Obras Públicas y Transporte (M.O.P.T. 1992) R.O.M. 0.3-91 oleaje. Anejo I. Clima Marítimo en el Litoral Español. Madrid, Centro de Publicaciones del Ministerio de Obras Públicas y Transportes

Mosso C, Mestres M, Sierra JP, Sánchez-Arcilla A, Goodes C (2009) Waves and surges in the Valencia Gulf. Variability rhater than climate change. J Coast Res 56:243-247

Pardo J (1991) La erosión antrópica en el litoral valenciano. Valencia, Generalitat Valenciana

Pérez-Chacón Espino E, Hernández-Calvento L, Yanes Luque A (2007) Transformaciones humanas y sus consecuencias sobre los litorales de las Islas Canarias. En Étienne. In: Paris S R (ed) Les littoraux volcaniques. Une approche environnementale. Clermont-Ferrand, pp 173-191

Puertos del Estado www.puertosdelestados.es

Rangel-Buitrago NR, Anfuso G (2010) Clasificación de temporales en el litoral SW de España. XIV Seminario Nacional de Ciencias y Tecnología del Mar, Colombia, pp 58-63

Rangel-Buitrago NR, Anfuso G (2013) Winter wave climate, storms and regional cycles: the SW Spanish Atlantic coast. Int J Climatol 33:2142-2156

Rangel-Buitrago NR, Anfuso G (2014) Temporales marítimos en el Atlántico español: clasificación, tendencias e impactos. En Botero CM, Monserrat AL, Pereira CI (ed) Radiografía de la costa. Múltiples miradas científicas de los sistemas socio-naturales costeros de Iberoamérica y el Norte de África. Editorial Academia Española, pp 37-53

Rodríguez-Báez JA, Yanes A, Dorta P (2017) Determinación y caracterización de situaciones de temporal marino e inundación costera por rebase del oleaje en San Andrés, NE de Tenerife (1984-2014). Investigaciones Geográficas 68:95-114

Sanjaume E (1985) Las costas valencianas. Valencia, Ed. Universidad de Valencia

Tsai CH, Chen CW (2011) The establishment of a rapid natural disaster risk assessment model for the tourism industry. Tour Manag 32(1):158-171. https://doi.org/10.1016/j.tourman.2010.05.015

Torres CG, Romero LE, Pérez-Chacón Espino E, Martel F, Dávila MP (1994) El papel de la prensa en el estudio de las catástrofes naturales en Gran Canaria (Islas Canarias, España). X Coloquio de Historia Canario-Americana 2:189-213

UN (2015a) Sendai framework for disaster risk reduction. United Nations, Geneva

UN (2015b) Paris agreement. In: Report of the conference of the parties to the United Nations Framework Convention on Climate Change (21st Session, 2015: Paris). Retrived December, vol 4, pp 2017

UNISDR (2009) Terminología sobre Reducción del Riesgo de Desastres. Estrategia Internacional para la Reducción de Desastres de las Naciones Unidas. United Nations, Geneva

Yanes A (2017) Desastres naturales en Canarias. La costa como espacio de riesgo en Tenerife. Sémata 29:67-89

Yanes A, Marzol MV (2009) Los temporales marinos como episodios de riesgo en Tenerife a través de la prensa (1985-2003). Revista de la Sociedad Geológica de España 22(1-2):95-104

Yanes A, Marzol MV, Romero C (2007) Temporales marinos en Tenerife: propuesta tipológica. IV Jornadas Nacionales de Geomorfología Litoral, Palma de Mallorca: 147-151

Van Westen CJ (2013) Remote sensing and GIS for natural hazards assessment and disaster risk management. Treat Geomorphol 3:259-298. https://doi.org/10.1016/B978-0-12-374739-6.00051-8

Publisher's Note Springer Nature remains neutral with regard to jurisdictional claims in published maps and institutional affiliations. 